\title{
LAS CAJAS DE SANTOS Y SU RELACIÓN CON LOS CIRCUITOS DE LA MEMORIA (ESTACIÓN SAN PEDRO)
}

\author{
LAS CAJAS DE SANTOS AND THEIR RELATIONSHIP WITH THE CIRCUITS OF \\ THE MEMORY (ESTACIÓN SAN PEDRO)
}

\author{
María Carolina Odone Correa ${ }^{1}$
}

\begin{abstract}
Este trabajo se refiere a las cajas de madera de San Antonio de Padua existentes en la localidad de San Pedro Estación o Estación San Pedro (Cuenca San Pedro-Inacaliri, II región, Antofagasta, Chile). El artículo se inserta en la discusión actual sobre la vida social de los objetos, siendo la etnografía, la visualidad y la etnohistoria las puertas de acceso para dar cuenta de estos cajones portátiles y sus vínculos con antiguos y actuales circuitos de gentes, memorias e historias diversas y compartidas. Se explora el cajón portátil en tanto manufactura europea y su inserción en los Andes del Sur, adquiriendo características propias tanto en Bolivia como en Perú. Se reconoce cómo los cajones de santos llegaron a San Pedro Estación, dando cuenta de sus vínculos y relación significativa con los circuitos de la memoria, sus viajes, el pasado, el presente y lo cosmológico.

Palabras claves: San Pedro Estación, cajones de santo, San Antonio de Padua, memorias.
\end{abstract}

This work refers to the San Antonio de Padua wooden boxes existing in San Pedro Estación or San Pedro Station (Cuenca San Pedro-Inacaliri, II region, Antofagasta, Chile). The article is inserted in the current discussion about the social life of objects, being ethnography, visuality and ethnohistory the access doors to account for these portable drawers and their links with ancient and current circuits of people, memories and stories diverse and shared. The portable drawer is explored in both European manufacturing and its insertion in the Southern Andes, acquiring its own characteristics in both Bolivia and Peru. It is recognized how the boxes of saints arrived at San Pedro Estacion, giving an account of their links and significant relationship with the circuits of memory, their travels, the past, the present and the cosmological.

Key words: San Pedro Estación, cajones de santo, San Antonio de Padua, memories.

\section{A Modo de Presentación}

Este trabajo se refiere a las cajas de madera portátiles existentes en la localidad de San Pedro Estación o Estación San Pedro que contienen figuras talladas de San Antonio de Padua (Figura 1). Y dos son los objetivos generales que se proponen. Por una parte, dar cuenta de su importancia; y por otra, articular estas cajas de madera portátiles con los antiguos y actuales circuitos de gentes indígenas, memorias sociales e historias diversas y compartidas. Se presenta un abordaje etnográfico, visual y etnohistórico a fin de alumbrar sus vidas sociales con realidades históricas, y dar cuenta de sus vínculos con las memorias y sus viajes en el contexto de las circulaciones de gentes indígenas en la Cuenca San Pedro-Inacaliri (II región, Antofagasta, Chile), y espacios adyacentes.
Este artículo se inserta en la discusión de la vida social de los objetos, comprendiendo las cajas de santos desde sus múltiples y variados movimientos de desplazamiento en el mundo social. Sus vidas o biografías no solo se vinculan con cadenas de producción o elaboración, sino que también con las trayectorias de circulación de los contextos de recepción de las mismas, y las subjetividades de los sujetos históricos que les van dando vida. Lo que a su vez permite reconocer a las cajas de santos como integrantes de una complejidad que articula personas, memorias sociales, procesos históricos y culturales, paisajes, prácticas sociales, económicas, rituales y religiosas que, en su conjunto, las van reensamblando no solo en el mundo social, sino que también contribuyen a construir constantes procesos de re-significación y producción de sentidos (Appadurai 1991; Latour 2008).

\footnotetext{
${ }^{1}$ Instituto de Historia, Facultad de Historia, Geografía y Ciencia Política. Pontifica Universidad Católica de Chile, Santiago, Chile.modoneco@uc.cl
} 


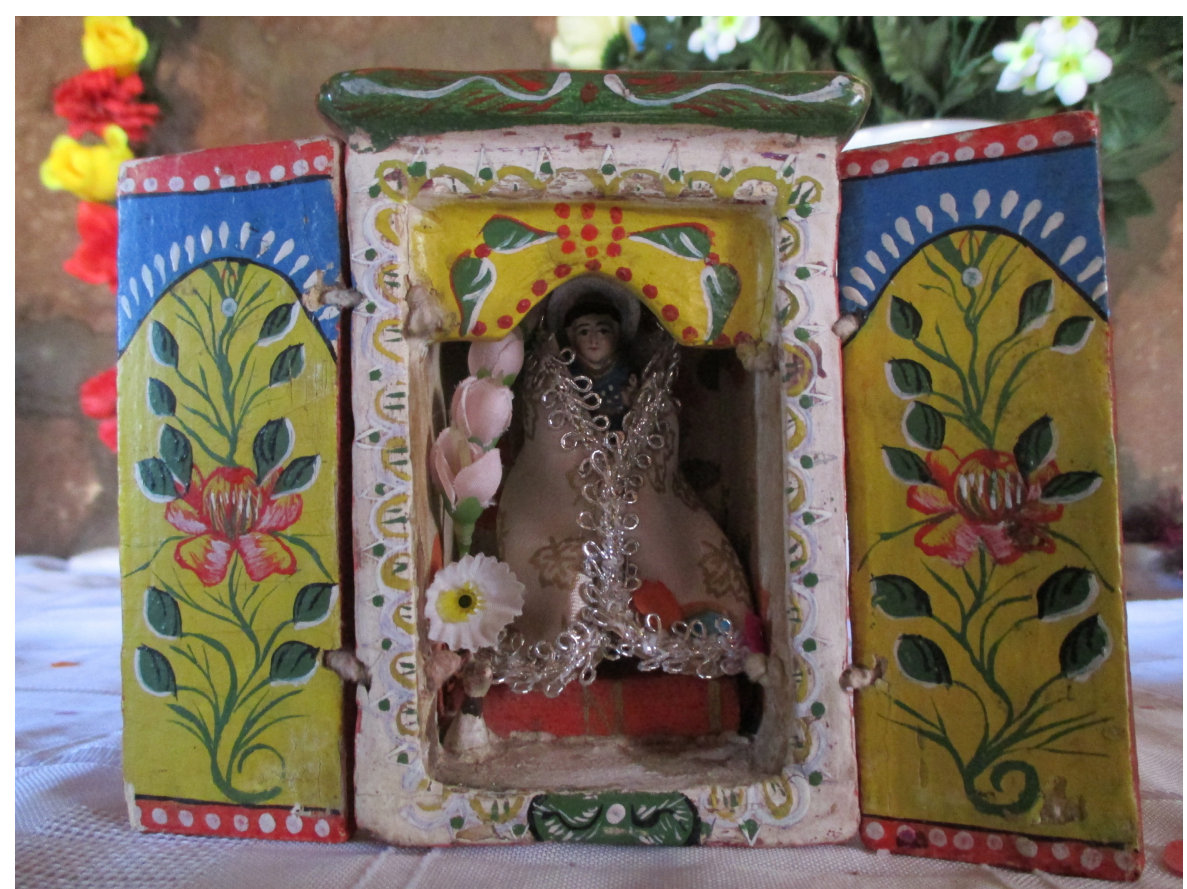

Figura 1. Vista de una caja de madera de San Antonio de Padua. Fotografía de Carolina Odone, junio 2017.

View of a wooden box of San Antonio de Padua. Photograph by Carolina Odone, June 2017.

Son los contextos de uso y circulación de los objetos los que pueden ser pensados como "actos vitales de transferencia, transmitiendo saber social, memoria y sentido de identidad a través de acciones reiteradas" (Taylor et al. 2011:50). En las cajas de santos hay intenciones o agencias, transmisiones orales, circuitos de memorias individuales y familiares que ofrecen posibilidades comunicativas para indagar en una sumatoria de contextos históricos vividos, antiguos y actuales.

Un aspecto que también resulta relevante de reconocer es que los cajones de madera portátiles no solo expresan prácticas transculturales que permite pensarlos como objetos que muestran sus tránsitos desde el mundo indígena al mundo de la modernidad, y desde la modernidad al mundo indígena (Dean y Leibsohn 2003; Thomas 1991). También en ellos es posible distinguir cómo los grupos sociales actúan y comprenden el mundo. Y en esa historicidad dan cuenta de agencias sociales, de momentos históricos en la corriente del proceso social transformador que contribuye a moldear y por la que es moldeada la vida de un grupo social o una localidad (Baudrillard 1969; Gell 1998; Miller 2005; Hoskins 2006; Latour 2008; Sillar 2009).

Las cajas de madera portátiles, y que en este caso particular guardan a San Antonio de Padua, no son expresiones de fusiones o sincretismos culturales. Son objetos que condensan apropiaciones selectivas, las que se constituyen en soportes de memorias colectivas múltiples.
Son esas memorias las que actualizan constantemente a las cajas de madera; y por ende son las prácticas culturales, totalmente enraizadas en los usos y costumbres, antiguas y nuevas, las que animan a los objetos. Así, estas cajas guardarían también las fuerzas de resistencias frente a las hegemonías. Son producciones de sujetos sociales colectivos y anónimos, donde el pasado, el presente y el futuro están enraizados en la cultura y sus producciones de sentido. Desde esa perspectiva

"no es la cultura andina [...], sino los andinos [...], quienes han resistido las fuerzas de la dominación social apoyándose en una memoria social de elaboración colectiva para comprender las hegemonías a que están sujetos, con el fin de redesplazarlas creativamente en forma de contrahegemonías (Abercrombie 2006 [1998]:59).

\section{Las Cajas de Santos Portátiles en los Andes del Sur}

El estudio de las cajas o cajones de santos portátiles tiene una importante tradición académica en Perú y Bolivia la que se adscribe a la línea de trabajo del complejo de la cajonería ritual-portátil campesina. Por un lado, se reconocen los cajoncitos de santos de los Andes bolivianos que cuentan con un solo recinto (Oros 2015). Y por otro lado, 
los retablos peruanos que anclan en dos tipos de manufacturas propias del área ayacuchana. Una está asociada a la elaboración de los cajones coloniales sanmarkos que, en general, tiene un techo de forma triangular, dos puertas batientes, y en su interior, al menos, dos pisos horizontales. Uno de ellos, el superior, está "conformado iconográficamente por los santos patrones del ganado y sus atributos: San Marcos (toro y vaca); San Juan (oveja), San Lucas (animales salvajes, león), San Santiago (jefe de los ganados), San Antonio (mula), Santa Inés (cabra)" (Quijada 2018:37). A su vez, y en el piso inferior "se ubican las diferentes escenas que conforman el ritual de la herranza" (Ulfe 2004:80). La segunda tradición de manufactura se inició hacia la década de 1940, y es conocida como la manufactura de los retablos, caracterizados por disponer de varios pisos, hasta siete pisos, divididos éstos en varias secciones, donde no solo se situaban imágenes de deidades cristianas, sino que también representaciones de escenas de la vida social local y comunitaria, incluso escenificaciones de memorias históricas del tiempo presente (Ulfe 2011; Golte y Pajuelo 2012).

Pese a las diferencias de la cajonería ritualportátil campesina en los Andes del Sur se reconocen similitudes. Por una parte, estas manufacturas eran elaboradas por artesanos santeros y/o imagineros, y eran los arrieros quienes solicitaban a esos artesanos la elaboración de los objetos (Arguedas 1998), los que eran vendidos y/o intercambiados en contextos de mercados, ferias y comunidades, para ser utilizados, a nivel familiar, en rituales asociados a la producción agrícola y ganadera, en ceremonias de curaciones y, como cajones altares portátiles para la celebración de misas, sobre todo en espacios rurales (Ulfe 2004:79).

Sin embargo, las cajas de santos son una manufactura que tiene una larga tradición y se asocian con formas materiales del arte religioso paleocristiano de los siglos VI y VII, el tríptico o altar portátil. Y en contextos de la evangelización temprana en los Andes del Sur, fueron traídos por los curas doctrineros para la realización de misas (Corrales Gaitán 1998). La capilla de santero o altar portátil fue un artefacto de rápida difusión durante el periodo colonial detectándose su presencia en espacios de comunidades rurales y en ámbitos de control de prácticas indígenas consideradas idolátricas (Garcés y Sánchez 2016). Se ha reconocido su rápida aceptación por parte de las gentes indias observándose en las cajas la presencia de Tata Santiago, La Virgen, Cristo, San Juan Bautista, San Marcos, San Isidro y San Antonio de Padua, acompañados de imágenes de aves y animales (Del Solar 1992; Castro 2013; Oros 2015). Siendo también interesante que la producción de cajones de madera tuviera su mayor desarrollo en el siglo XIX, producción que, en el caso de los Andes bolivianos, no solo estaba dirigida a espacios situados en las cercanías de ciudades como La Paz, Oruro, Sucre, Potosí y Cochabamba (Sánchez y Gracia 2013).

¿Cuáles habrían sido los espacios de producción de las cajas de madera y sus imágenes? En el contexto de las imágenes, en la colonia temprana, la importación de piezas talladas y policromadas españolas fue muy significativa (Kennedy 1998). Sin embargo ya en el siglo XVII en Cusco, Ayacucho, Copacabana, en el lago Titicaca, y en La Plata (hoy Sucre) existían talleres de artesanos indígenas de escultura en maguey-pasta-tela encolada. Por otra parte, Potosí fue un importante lugar de producción de imágenes y objetos asociados a la imaginería cubriendo demandas tanto urbanas como rurales, siendo sus productores, artesanos santeros y/o imagineros de ascendencia indígena, los que producían objetos de indios para mercados de y/o demandas de gentes indias (Querezaju 1995; Odone 2018, 2019).

\section{La Devoción de San Antonio de Padua más Allá de San Pedro Estación}

La devoción a San Antonio de Padua no solo está presente en San Pedro Estación ${ }^{1}$, puesto que en tanto santo patronal, también está activa en espacios cercanos, como la localidad de San Antonio de Ollagüe, en dirección nor-este, y distante de aquella por cerca de $120 \mathrm{~km}$. Igualmente su devoción se constata en el altiplano de Lípez, específicamente en la provincia Sud Lípez. También es importante la devoción en áreas de los departamentos de Cochabamba, Tarija y Oruro, entre otros. A su vez, y en el ámbito de la puna jujeña, en la localidad de San Antonio de los Cobres, la devoción está presente. Ello permite plantear la existencia de una malla geográfica devocional que se articula en el área reconocida por los estudios andinos como Andes del Sur.

En los Andes del Sur, la devoción a San Antonio de Padua fue patrocinada por los franciscanos, siendo además el Tercer Concilio Limense (15821583), un punto de partida muy importante para el uso de imágenes, y por ende, su circulación, asociadas a la evangelización de las poblaciones indígenas (Valenzuela 2016). En ese contexto, también destacan el uso de altares portátiles utilizados por los curas doctrineros, sobre todo en espacios rurales, para la celebración de misas. Ya a fines del siglo XVI, y en ámbitos de la Audiencia de Charcas, se detecta la presencia de imágenes de bulto 
encajonadas insertas en contextos de celebración de misas y también presentes en el interior de las casas (Castro 2008; González 2003; Gutiérrez 1995; Odone 2018, 2019).

Cuando San Antonio de Padua comienza a difundirse en imágenes tridimensionales, es decir en esculturas medianas/grandes/pequeñas, se instalan dos iconografías del santo. Una de ellas presenta la imagen del santo estilizado, ennoblecido, vestido con su hábito de color marrón o azul. En algunos casos y sobre el hábito lleva una capa corta. El santo es representado de pie, en uno de sus brazos sostiene al Niño Jesús, y en el otro lleva un lirio o una palma. Se destaca, en esta representación literalizada, que se trata de un santo de apariencia muy juvenil. La otra representación de San Antonio de Padua es la de un santo grueso y de baja estatura, representación menos común y menos extendida. Ello plantea una posibilidad de datación en el sentido de que desde la historia del arte, la exageración e idealización de ciertos elementos formales de la decoración de las imágenes se adscribe a formas representacionales propias del estilo barroco de fines del siglo XVIII, y justamente es esa modalidad de representación la que se popularizó desde entonces y hasta el día de hoy (Schenone 1992).

Respecto de la devoción a San Antonio de Padua el antropólogo Edmundo Magaña, ya fallecido, señala que constituye en Portugal y en buena parte de España, la figura más importante del santoral. Es el santo al que se le pide encontrar desde lo que se pierde en la casa hasta que le encuentre novio a las jovencitas. Por ello es considerado un santo cocinilla o cocinero que le gusta estar metido en cosas domésticas, lo cual es propio de mujeres (Magaña 1997).

En contextos etnográficos de los Andes del Sur se observa que San Antonio de Padua tiene patrocinios variados. Se le pide por la falta de alimentos, para encontrar no solo las cosas pérdidas, sino que también los amores ausentes y su falta. Es el santo de los arrieros, de los viajes, de los rebaños, de las mulas, burros, llamas y de los animales domésticos o criados. Es un santo que condensa significados superpuestos, transitando entre los planos de lo doméstico, del amor, la buena fortuna y la abundancia de la producción económica-ganadera, entre otros (Bugallo 2010; González 2003; Odone $2018,2019)$. A su vez, es un santo milagrero o taumaturgo, su figura tallada es como un amuleto que se guarda, se vela, se acompaña, justamente para encontrar lo extraviado o perdido, como los animales, pero también para curar enfermedades y acompañar a las parteras en su oficio (Chávez 2004; Gentile 2013).

\section{En San Pedro Estación, los Cajoncitos de Santos}

San Pedro Estación o Estación San Pedro está ubicada en el interior de la región de Antofagasta, en la Cuenca San Pedro-Inacaliri, formando parte, junto a otras localidades, del área de quebradas del Alto Loa, y situada en un paisaje de desierto absoluto, sobre los $3.240 \mathrm{msm}$. Hoy en día, el pueblo está casi deshabitado, sus habitantes residen mayoritariamente en Calama. No por ello cortaron sus lazos sociales con San Pedro Estación, viajando, por ejemplo, cada año, a la celebración de la fiesta de San Antonio de Padua, patrono de la localidad, la que se realiza entre el 11 y el 15 de junio. A su vez, la localidad es visitada, en distintas épocas del año, por sus comuneros para realizar trabajos de arreglo o construcción de infraestructura familiar y/o comunal. De modo intermitente residen en la localidad trabajadores del ferrocarril que realizan tareas asociadas a la mantención de líneas férreas y contratistas de empresas mineras. El poblado está conformado por viviendas, en general, construidas de piedras con argamasa, algunos techos están recubiertos con paja, aunque en su mayoría se observa la incorporación de calaminas en tanto materiales que los recubren (Figuras 2, 3 y 4).

Uno de los ejes que organiza el asentamiento es la estación de ferrocarril, cuya existencia y eje ferroviario asociado, corresponde al antiguo trazado de la ruta del Ferrocarril AntofagastaUyuni-Oruro de 1888-1889, situándose la estación de San Pedro en la punta de San Pedro, en la localidad homónima (Espinoza 1897:106) (Figuras 5 y 6). Esta extensión ferroviaria estuvo a cargo de la compañía The Antofagasta (Chili) and Bolivia Railway Co. Ltda, línea, con sus respectivos ramales, en total funcionamiento desde comienzos de la década de 1890 (Correa 2013; González 2008; González 2011; Sanhueza 2011). Inicialmente fue un tren de carga y a comienzos del siglo XX fue también un tren de pasajeros. A partir de la década de 1980, dejó de ser un tren mixto para transportar solo carga. Hoy en día el Ferrocarril de Antofagasta (FCAB) pertenece al grupo minero Antofagasta Chilean Copper Mining Group.

San Pedro Estación cuenta con dos iglesias, llamadas por los habitantes del lugar, la iglesia grande y la iglesia chica o capilla. La diferencia de las iglesias remite a sus dimensiones espaciales, pero a su vez, a una cierta jerarquía simbólica dado que en la iglesia grande se encuentra el santo grande, la figura tridimensional del patrono de la localidad, San Antonio de Padua. A su vez, tanto la iglesia grande como la capilla o iglesia chica, están asociadas, respectivamente, al sector alto y bajo del asentamiento, congregando 


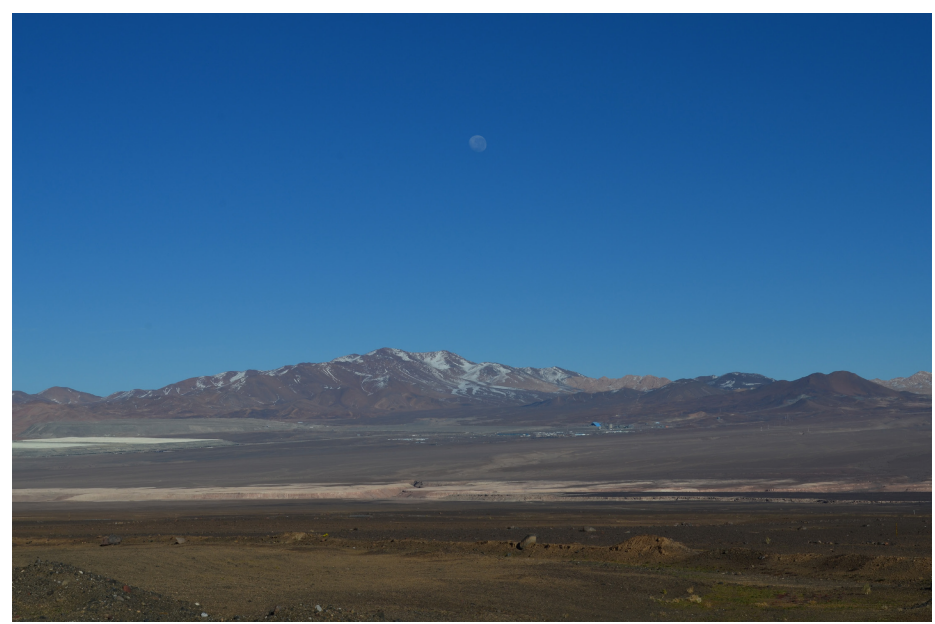

Figura 2. Vista del espacio en torno al poblado de San Pedro Estación. Fotografía de Carolina Odone, junio 2017.

View of the space around San Pedro Estación. Photograph by Carolina Odone, June 2017.

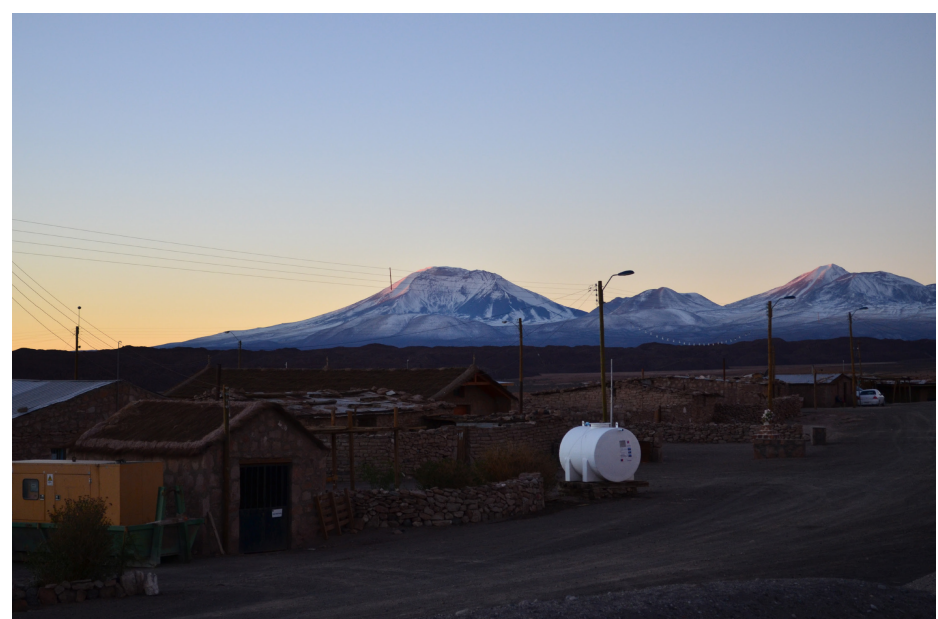

Figura 3. Vista de San Pedro Estación. Atrás se divisan los volcanes San Pedro y San Pablo. Fotografía de Carolina Odone, junio 2017.

View of San Pedro Estación. Behind you can see the San Pedro and San Pablo volcanoes. Photograph by Carolina Odone, June 2017.

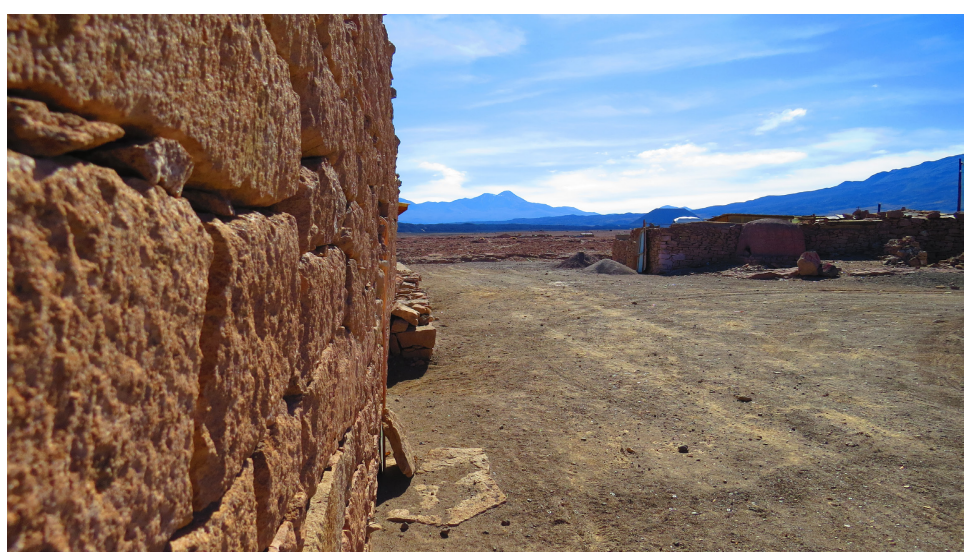

Figura 4. Vista de San Pedro Estación. Fotografía de Carolina Odone, junio 2017.

View of San Pedro Estación. Photograph by Carolina Odone, June 2017. 


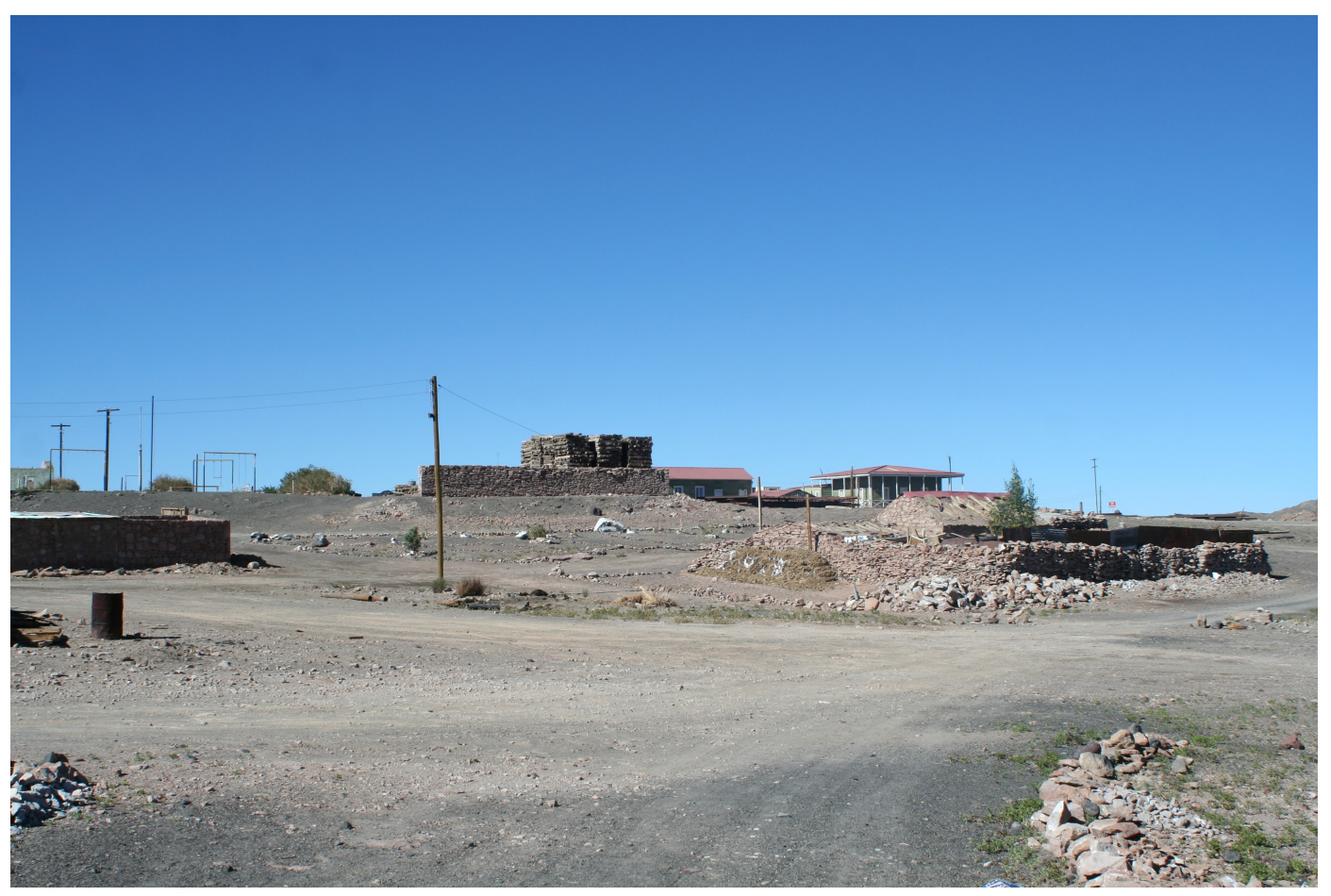

Figura 5. Vista de la estación de trenes. Fotografía de Carolina Odone, junio 2016.

View of the train station. Photograph by Carolina Odone, June 2016.

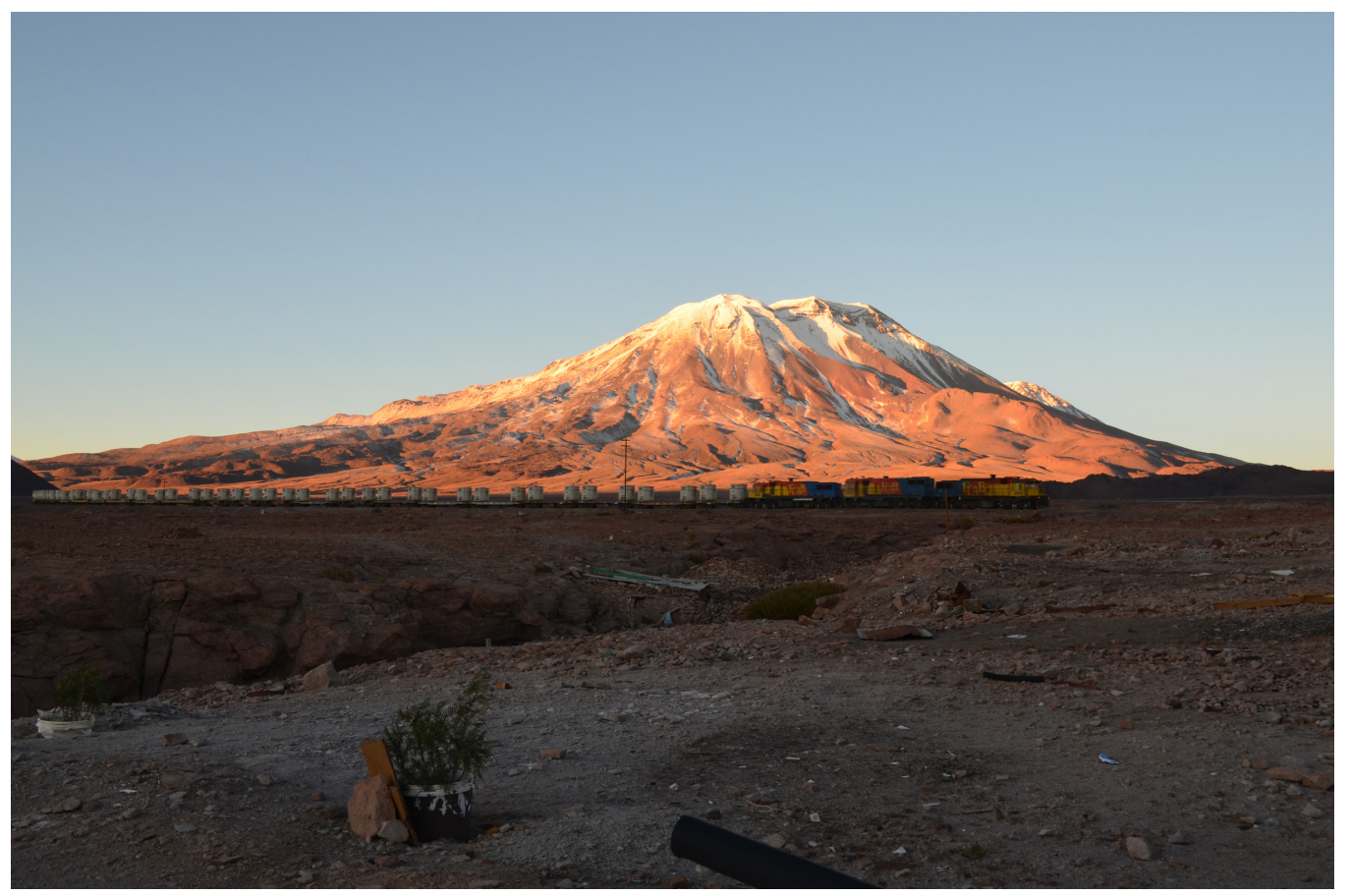

Figura 6. Vista del trazado ferroviario. Fotografía de Carolina Odone, junio 2017.

View of the railway track. Photograph by Carolina Odone, June 2017. 
a las familias que habitan en ellos (Figuras 7 y 8). También, y a partir de esa ordenación del sector alto y bajo del asentamiento, se sitúan dos sedes sociales, junto a sus cocinas comunitarias, aunque recientemente se construyó una tercera sede social levantada por una familia de la localidad.
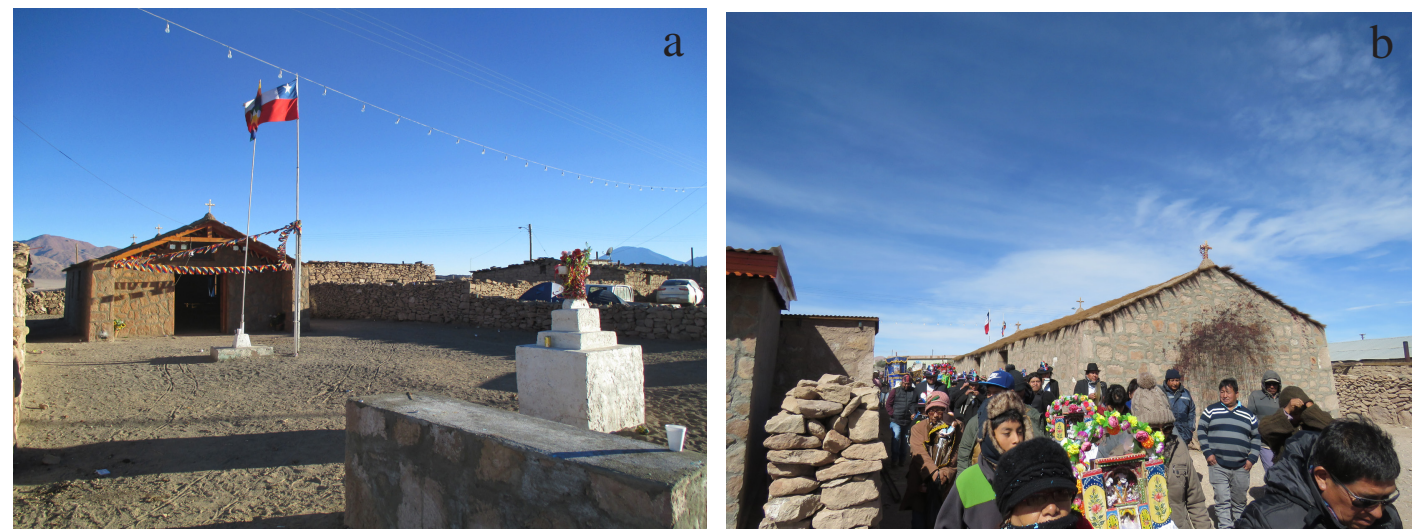

Figura 7. (a) La iglesia grande de San Pedro Estación. (b) Desde la iglesia grande de San Pedro Estación. Fotografías de Carolina Odone, junio 2017.

(a) The large church of San Pedro Estación. (b) From the large church of San Pedro Estación. Photographs by Carolina Odone, June 2017.

En cada una de las iglesias, en sus altares, se guardan, respectivamente, tres cajas de San Antonio de Padua, por ende seis son las cajas de santos de San Pedro Estación. Las cajas de madera tienen un techo horizontal, dos puertitas rebatibles, decoradas con motivos florales, geométricos o con otras imágenes, aunque las flores son el motivo más extendido, las que se suelen combinar con motivos geométricos².

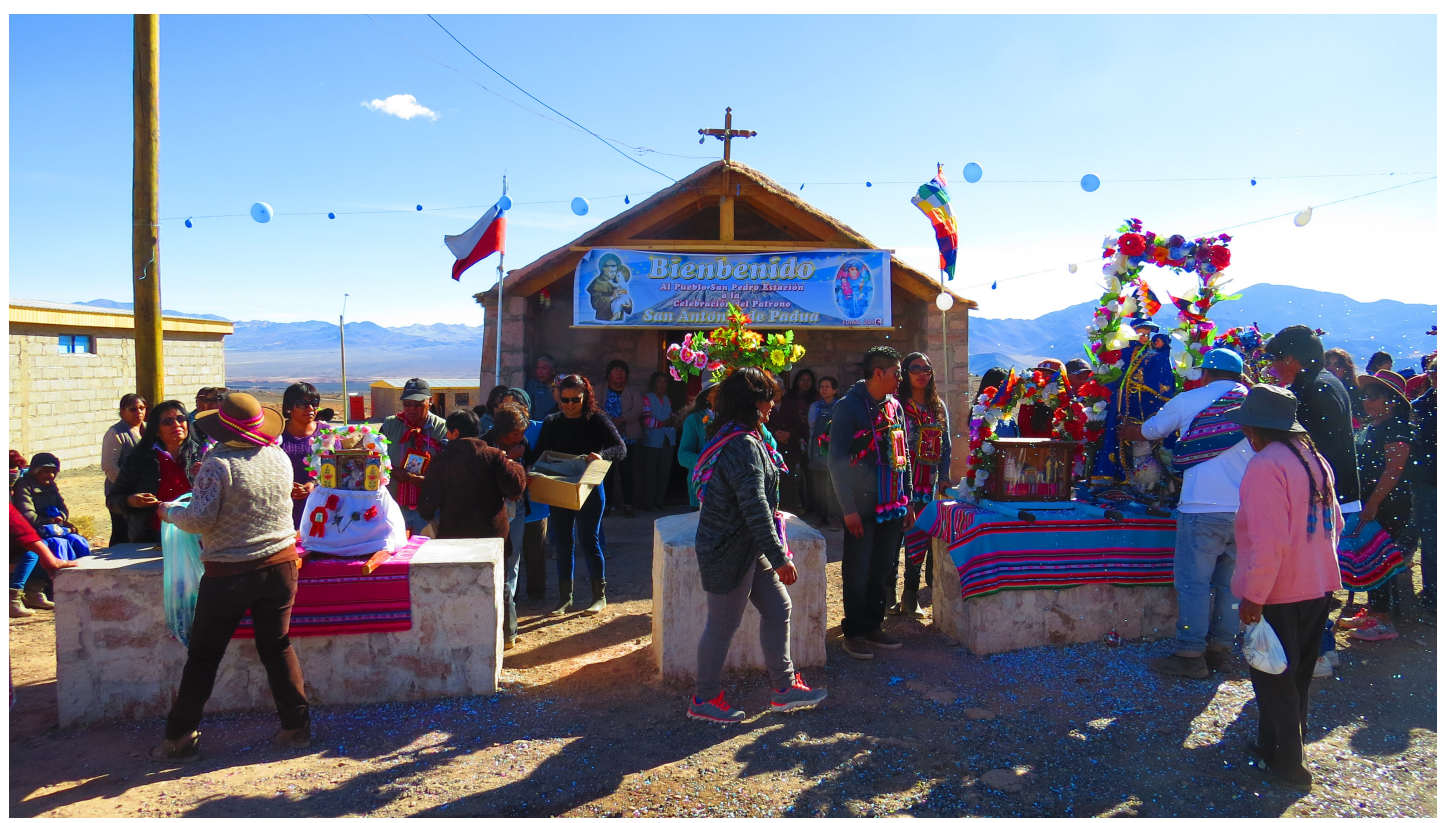

Figura 8. La iglesia chica o capilla de San Pedro Estación. Fotografía de Carolina Odone, junio 2017.

The small church or chapel of San Pedro Estación. Photograph by Carolina Odone, June 2017. 
Las cajas presentan una tendencia a la regularidad en la forma, por ende a la simetría, colores saturados y contrastantes, predominando el amarillo, el rojo, el verde y el azul. Su singularidad plástica es la estética del contraste en el contexto de la regularidad de la forma. En su espacio interior se ubica un santo estilizado, rodeado de flores, las que muchas veces no permiten verlo; y a los pies del santo, hay llamas, corderos y en algunos casos, la figura de un moro. Se representa a San Antonio de pie, sosteniendo al Niño Jesús, llevando también una flor en una de sus manos (Figuras 9 y 10).
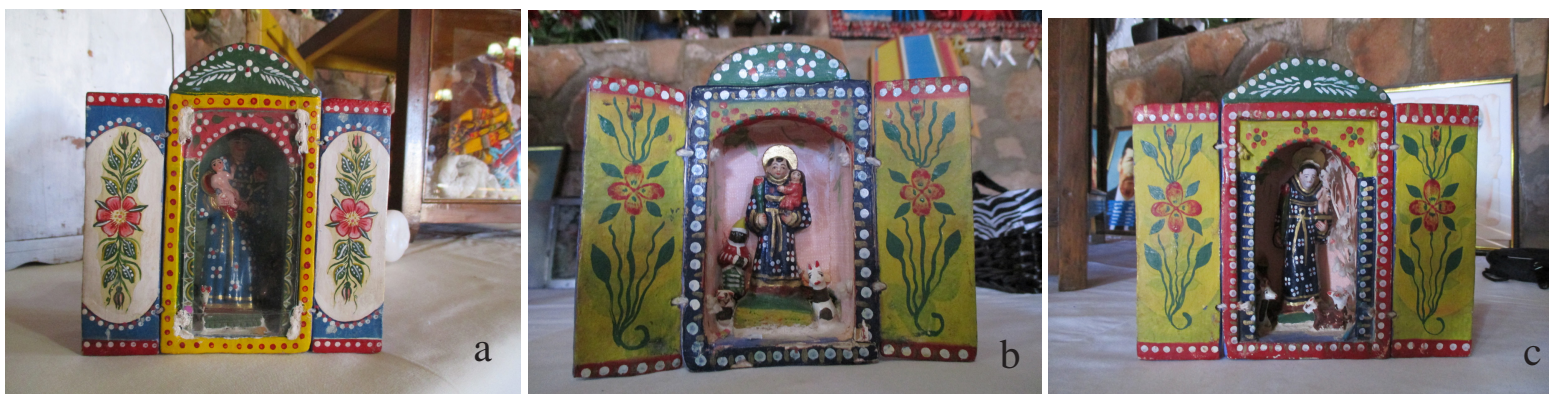

Figura 9. a, b y c. Vista de las cajas de madera de la iglesia grande. Fotografías de Carolina Odone, junio 2017.

View of a wooden box of the large church. Photographs by Carolina Odone, June 2017.

En el ámbito del actual territorio de Bolivia, las cajas de madera que guardan santos tienen un techo, generalmente, horizontal, llano o liso. En relación a su división interior, solo presentan un único recinto o espacio donde se disponen las imágenes cristianas junto a otros objetos e imágenes allí contenidas. Y en relación a las puertas, pueden o no contar con ellas. Las deidades cristianas que se presentan están asociadas a la producción agrícola y ganadera. Las cajas de madera pueden ser de tres tamaños, grandes, pequeñas y reducidas, y son llamadas por las comunidades campesinas como "Tata cajoncitos", "Mama Cajoncitos", "Cajoncitos de santos", y son elaboradas por cajoneros o imagineros/santeros (Oros 2015). Siendo además una manufactura propia de espacios situados en las cercanías de las actuales ciudades de La Paz, Oruro, Sucre, Potosí y Cochabamba (Macera 1981, 1982; Sánchez 2015:21).

Las características estéticas y formales referidas permiten proponer que las seis cajas de San Pedro Estación encajan dentro del corpus de objetos cajas de Bolivia, y por ende proceden de una factura propia de los Andes bolivianos.
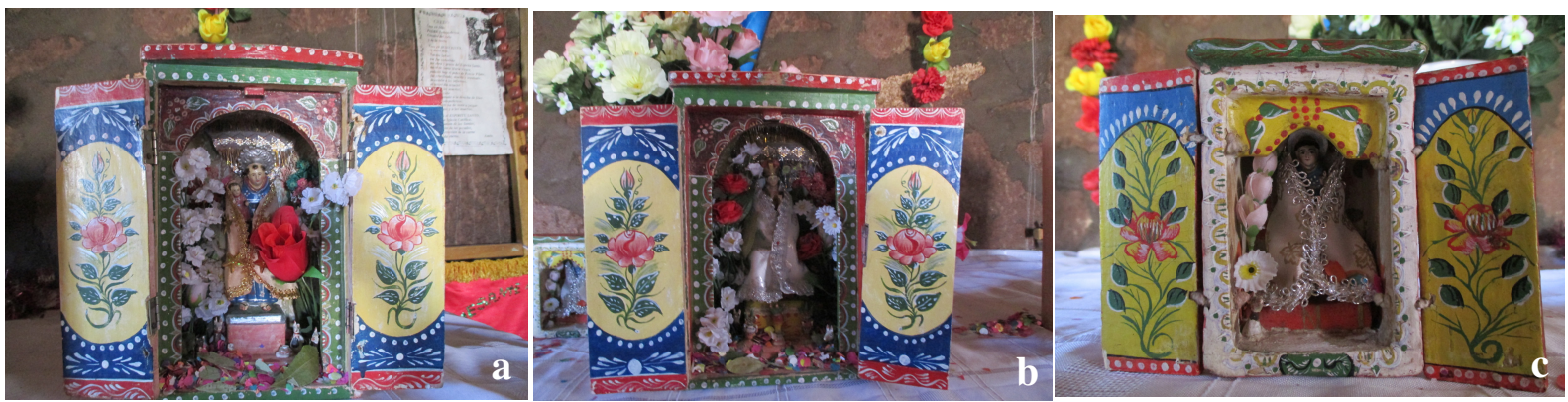

Figura 10a, b y c.Vista de las cajas de madera de la iglesia chica o capilla. Fotografías de Carolina Odone, junio 2017.

View of a wooden box of the small church or chapel. Photographs by Carolina Odone, June 2017.

\section{¿Cómo Llegaron las Cajas de Madera a San Pedro Estación?}

Las seis cajas de santos que se encuentran en las dos iglesias de San Pedro Estación no pertenecen a familias originarias de la localidad, las que en su mayoría proceden de estancias situadas en la cuenca del Río San PedroInacaliri, particularmente provenientes de las estancias de Ojos de San Pedro, Colana, Cavana o Cabana (Figura 11). ¿Qué fue lo que ocurrió? ¿Cuáles serían las razones 


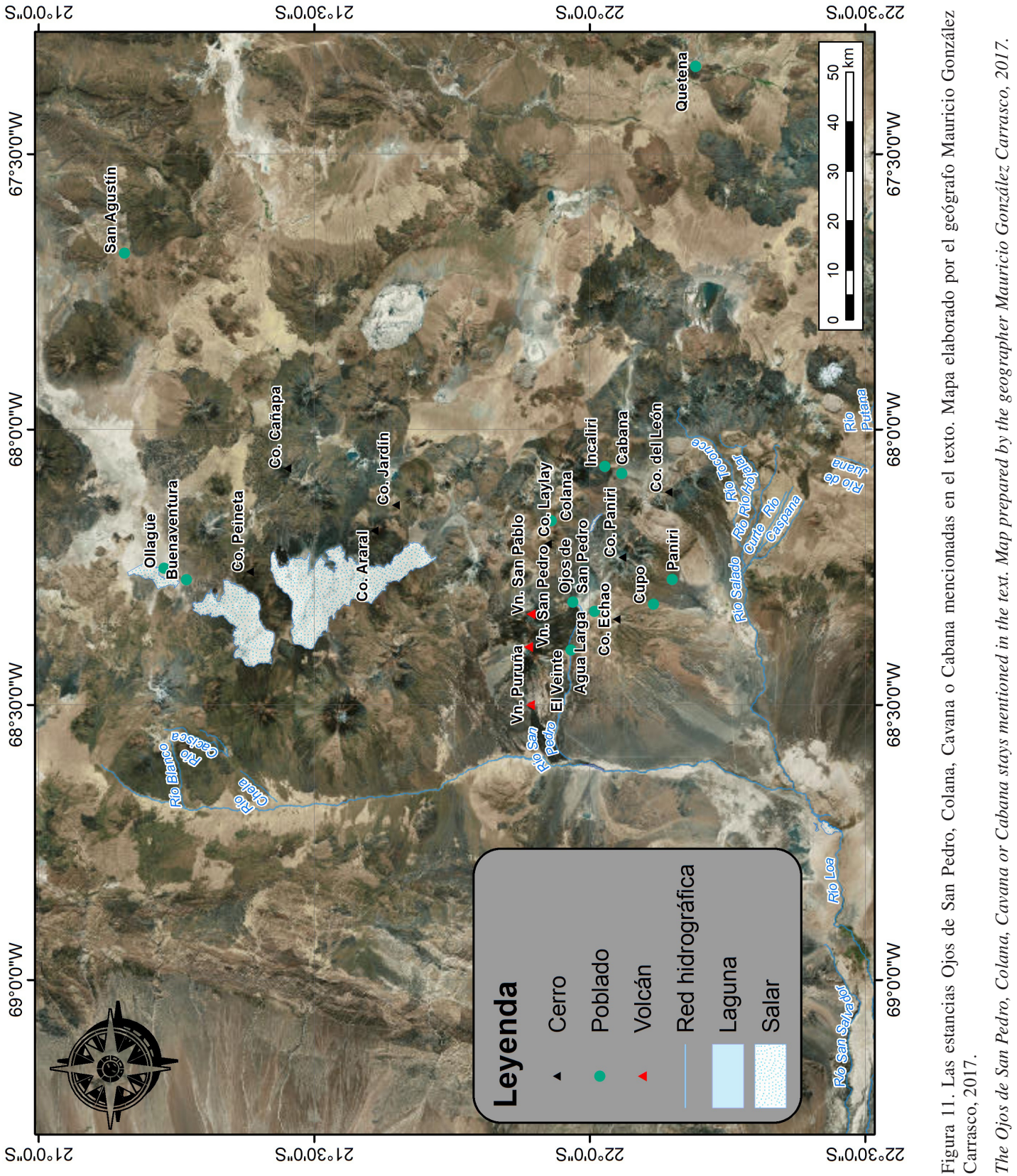


que explican estas migraciones a San Pedro Estación y la presencia de las cajas de madera en las dos iglesias?

La presencia de estos objetos ancla en procesos de diáspora forzosa de familias que debieron abandonar sus territorios de origen debido a los efectos ocasionados por las demandas de agua que, con mucha fuerza, comenzaron a requerir empresas mineras en la década de 1950. Ello fue el inicio de la migración de familias pastoras de llamas, residentes en espacios de vega de la cuenca San PedroInacaliri, como Ojos de San Pedro, Colana y Cavana o Cabana, las que se vieron obligadas a dejar sus estancias, trasladándose, algunas de ellas, a la localidad de San Pedro Estación. Ya en el año 1958, comenzó a observarse que fue aumentando la necesidad de empresas mineras como la compañía Chile Exploration de contar con aguas de la cuenca del Río San Pedro y espacios hídricos asociados (Yañez y Molina 2008:182).

Sin embargo, esta captación de aguas no fue un fenómeno propio de la segunda mitad del siglo XX. Existen indicios que permiten reconocer que ya a fines del siglo XIX se efectuaron concesiones o mercedes de agua a empresas, tal como se desprende de un Boletín de inspección de geografía y minas:

21 de Enero de 1888.-Ley de la República que concede á la Compañía de Huanchaca las aguas del Loa para surtir de agua á la ciudad de Antofagasta. Esta concesión localizó al río San Pedro por Decreto Supremo de 24 de Junio de 1889 (Archivo Nacional de la Administración [ARNAD], Ministerios y Servicios Públicos, Ministerio de Obras Públicas. v. 2464, 1912, f. 199r).

A su vez, y a comienzos del siglo XX, se observa que:

esa concesión es hoi de propiedad de The antofagasta (Chili) and Bolivia Railway Company Limited, como se acredita con la escritura de Febrero de 1904 (ARNAD, Ministerios y Servicios Públicos, Ministerio de Obras Públicas. 'Memoria esplicativa', 1913 [1912], v. 2535, sf).

O bien en 1907, donde se reconoce que:

De conformidad con el art. $2^{\circ}$., del Decreto de 8 de Febrero de 1907, que reglamentó las concesiones de aguas, de ríos ó esteros de uso público, para usos industriales, su representada expresa[...] la ubicación precisa de la boca-toma del canal de derivación, seria en los manantiales de donde nace el rio San Pedro, y que se denominan 'Ojos de San Pedro', y el punto de restitución de las aguas, estará á 22 kilometros en línea recta, aguas debajo de la boca-toma (ARNAD, Ministerios y Servicios Públicos, Ministerio de Obras Públicas, 1918, v. 2876, fs. 2r-3r).
De este modo ya en la década de 1910 se pueden datar, para la Cuenca San Pedro-Inacaliri, efectos de los drenamientos de aguas destinadas a la minería regional y abastecer de agua potable a la ciudad de Antofagasta, junto a las demandas que exigía el trazado del Ferrocarril Antofagasta-La Paz. Aguas que se captaron desde ríos, ojos de agua, napas subterráneas, y que estaban destinadas a la mantención de vegas utilizadas por familias indígenas para la reproducción y engorda de sus rebaños de llamas, burros y corderos, siendo esta economía comunal ganadera y forrajera uno de los modos de vida preponderantes en esta zona de quebradas altas, la que se complementaba con la producción de carnes, la elaboración de prendas textiles como frazadas, ponchos, junto a la preparación de cueros, producciones que se intercambiaban con espacios vecinos como Cupo, Paniri, Toconce y Caspana por hortalizas, maíz, quinua, frutas y otros recursos necesarios a su economía familiar (Aldunate 1985; Choque et al. 2008).

\section{Así, se reconoce que:}

producto de la sistemática contaminación y la desecación que sufrió el río San Pedro en ese sector, provocado por la minería del cobre, su población comenzó a abandonar el pueblo progresivamente. Cuando CODELCO empieza a desarrollar un alto nivel de producción industrial en los años cincuenta, las familias de la localidad se trasladaron a la estación de ferrocarriles contigua en espera que les devolvieran sus aguas, sin embargo, ello nunca sucedió por lo que deciden bajar a Calama a buscar mejores expectativas de vida y es así como prácticamente toda la comunidad de San Pedro Estación vive actualmente en Calama (Valenzuela 2006:177).

Hoy en día, en sectores de la cuenca del Río San Pedro se observan (Figuras 12 y 13):

extensos campos de pastoreo cruzados por cañerías de distinto diámetro; un embalse que almacena agua y corta el fluir del río; campamentos de prospección de aguas de CODELCO; motores y bombas que funcionan en el sector de Ojos de San Pedro; tropillas de vicuñas que bajan a beber en los orificios de las cañerías; grandes zanjas secas que atraviesan la antigua vega; numerosas estancias con sus corrales, casas y zonas de cultivo abandonados, y una iglesia derruida en Ojos de San Pedro. Este paisaje desolador es quizá el más claro testimonio de la influencia que ha tenido la gran minería del cobre en el despoblamiento de zonas de antigua data de ocupación (Yañez y Molina 2008:187). 


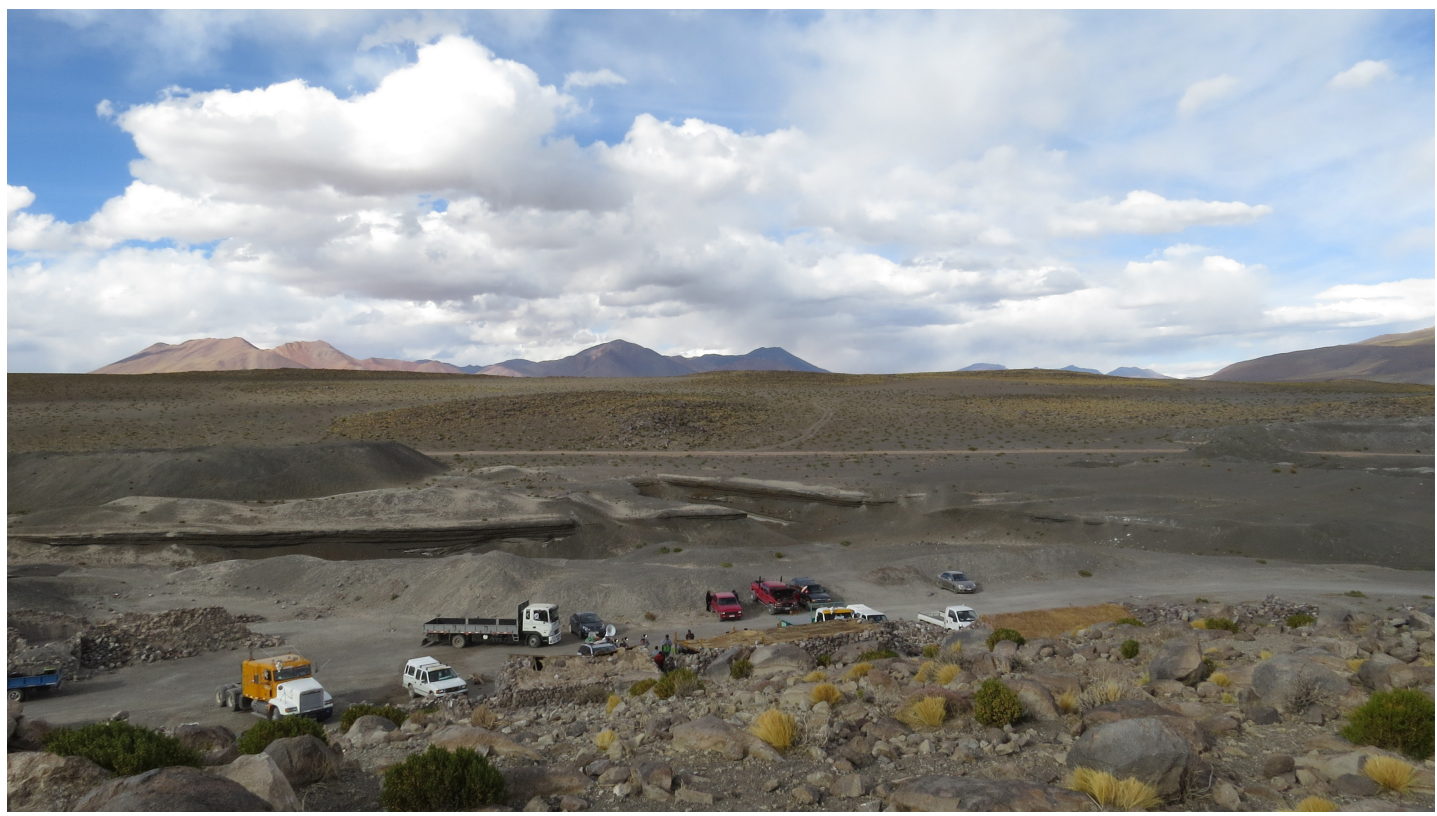

Figura 12. Vista actual de Ojos de San Pedro. Fotografía de Carolina Odone, junio 2017.

Current view of Ojos de San Pedro. Photograph by Carolina Odone, June 2017.

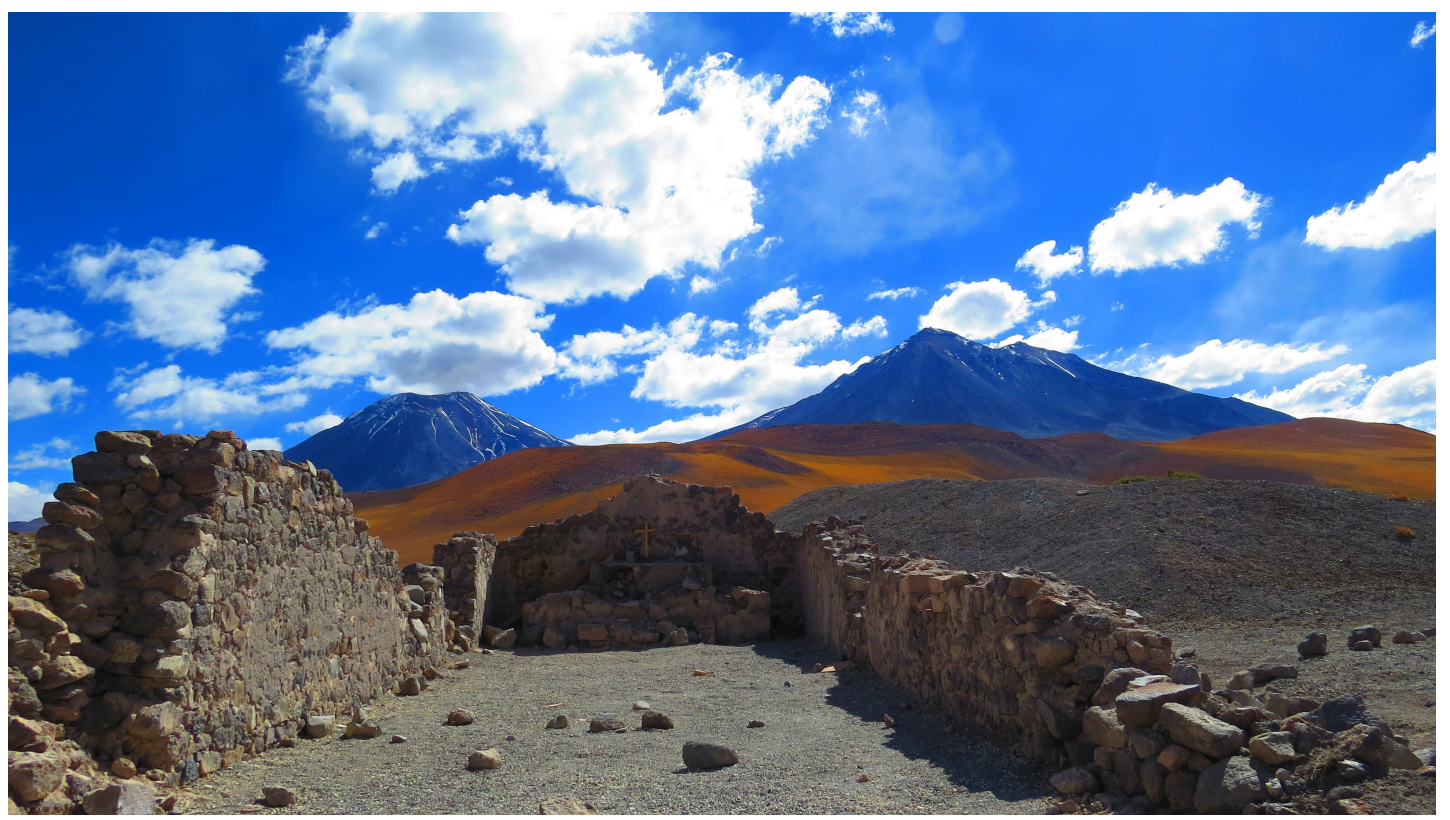

Figura 13. Vista de la iglesia destruida de Ojos de San Pedro. Fotografía de Carolina Odone, junio 2017.

View of the destroyed church of Ojos de San Pedro. Photograph by Carolina Odone, June 2017. 
Así se fueron secando "las vegas de Ojos de San Pedro, Colana [...] la explotación de azufre envenenó las aguas de la vega de Cabana. Se extrajo toda el agua del Linzor y parte importante de la del río Toconce" (Aldunate 1985:136-137). Ocasionando, por ejemplo, que "los habitantes de Ojos de San Pedro tuvieron que abandonar esta vega para trasladarse a otros lugares o irse a Calama, perdiendo casas, animales, enseres y su sistema de vida" (Aldunate 1985:137).

Los habitantes de Ojos de San Pedro tuvieron que abandonar esa vega, proceso que ya fue irreversible entre las décadas de 1960 y 1970 . A su vez, habitantes de otras estancias también vivieron las mismas consecuencias de dejar sus lugares de ocupación, como los parajes de Abra Chica, Colana, Cabana, y espacios situados entre los kilómetros 20 y 40 del curso del Río San Pedro. Y cada una de esas diásporas forzosas significó migrar con los enseres más queridos, entre ellos, las cajas de madera con el santo milagrero, siendo sus protagonistas las familias Huanca, Cruz Vilca, Esquivel Puca, Bautista Ayavire, entre otras, cada una de las cuales dejó sus cajas de madera en las iglesias de San Pedro Estación (Choque et al. 2008).

Así lo recuerda la señora Simona Bautista Ayaviri, originaria de Abra Chica, estancia situada más arriba de Colana. La cajita más pequeña que se encuentran en la capilla o iglesia chica de Estación San Pedro, le pertenece, era de su abuelita materna, Esperanza Ayaviri, y ella se la dejó a su mamá. Cuando sus padres murieron la señora Simona heredó la cajita y la mantuvo con ella hasta que la dejó en la iglesia o capilla chica dado que no la podía cuidar o hacerse cargo, “ ¿cómo lo voy a andar trajinando yo?", "yo he trabajado mucho y ahora ya me llegó la vejez". Ella recuerda que la cajita la tenían "así en un rinconcito, le prendíamos velitas". Y su papá le dijo "cuida el santito porque hace milagros, yo casi no me enfermo, le tengo fe al santito a los dos santitos, San Antonio más grandecito y el más chiquito"3.

Lo mismo sucedió con la caja de San Antonio que pertenecía a doña Victoria Huaca, cuyos padres tenían a los santitos, particularmente su papá don Miguel Huaca Salvatierra, quien los trajo de Bolivia. Don Miguel vivió en distintos sectores de la Cuenca San Pedro-Inacaliri. Nació en Cavana, y también vivió en el kilómetro 40 "que me contaban que estaba la capilla donde tenía su santo" 4 . Luego los padres migraron al kilómetro 20 y también vivieron en Ojos de San Pedro. Cuando la señora Victoria se casó con don Francisco Luizaga, los santitos se depositaron en la capilla o iglesia chica.
Recuerda la señora Irma Choque:

Porque ese San Antonio es de la abundancia donde si usted mata un llamo, las abuelas contaban si la sangrecita salta así como tshhh así decía el abuelo [don Miguel Huaca] va a haber más tropa el otro año, va a haber más y así era, se reproducían los corderos, los llamos, en esos tiempos habían burros ${ }^{5}$.

Don Olegario Carales señala que:

La gente de todas estas partes, de toda esta región y de Bolivia y esas partes, le tenían mucha fe a San Antonio y por eso es que siempre casi en todas las casas había una imagen de San Antonio, era muy adorado, muy querido, porque era muy milagroso ${ }^{6}$.

Es también significativo que:

Según mi papá, decía que sí, muchas veces los animales en la noche buscando el mejor pasto se perdían... entonces el dueño cuando los iba a buscar, me faltan cinco, los buscaba todo el día y no los podía encontrar y volvía a la casa y le prendía sus velitas a San Antonio y le decía, San Antonio ayúdame a encontrar mis animales, al otro día salía a buscar y los encontraba, por eso que la gente tenía a San Antonio en sus casas, le tenían fe al santo, porque cuando las mujeres estaban embarazadas, le prendían una vela para que la mujer se mejorara bien sin problemas y asî sucedía pero siempre había un porcentaje de uno en cincuenta o en cien que las mujeres morían en el parto porque en ese tiempo no había lo que hay ahora, por eso que la gente, tenían su San Antonio para prenderle velas y pedirle ${ }^{7}$.

Con estas circulaciones de las cajitas, atrás quedaban los tiempos en que esas vegas estaban ocupadas por rebaños de llamas, corderos y burros, como también los tiempos en que los santos, en sus cajas, se situaban al interior de las viviendas, se le prendían velas para que los animales extraviados regresasen, se les rezaba para que las tropas de animales fuesen abundantes, o bien acompañaban, con una velita encendida, los partos de las señoras. Esas cajas formaban parte de un legendario familiar, de sistemas de creencias y valores, de mundosvisiones y categorías de pensamiento donde ancestros y presagios seguían moviendo su mundo, sus vidas y la de sus difuntos.

Las familias protagonistas viajaron desde distintos puntos de la Cuenca San Pedro-Inacaliri a 
Estación San Pedro, y en esa travesía marcharon también las memorias sociales y familiares de sus cajas, que habían sido marginalizadas por efectos de las captaciones de aguas de sus espacios hídricos para usos industriales y urbanos-domiciliarios.

\section{Otras Circulaciones de las Memorias de las Cajas}

Más existen otras circulaciones que vivieron las cajas de madera de San Antonio de Padua. Las memorias familiares dan cuenta que entre las décadas de 1930 y 1940, las cajas que estaban en la iglesia de Ojos de San Pedro y que posteriormente fueron trasladadas a San Pedro Estación, llegaron desde la localidad de Quetena, en el sur-este de Lípez (Bolivia). Y fueron traídas por la familia CruzEsquivel. La señora Miguelina Ramos Mendoza señala que ${ }^{8}$ :

Los santos vienen del Ojo de San Pedro, al Ojo de San Pedro llegaron de Bolivia, de Quetena los santitos, los San Antonio en las urnas chicas, llegaron al Ojo de San Pedro porque mi abuelito [Lucas Cruz Vilca casado con Feliciana Esquivel Puca, sus abuelitos maternos], tenía llamos, entonces cuando se le perdían los llamos, tenía que andar detrás de los llamos y después le dijeron otros abuelitos, mas abuelitos que se trajera un San Antonio, los San Antonio cuidan los llamos y se perdían los llamos mi abuelito iba a la iglesia y le pedia a los San Antonios que aparezcan los llamos y en la mañana aparecían los llamos, toda la noche no sé dónde caminaban, pero en la mañana aparecían bajando el cerro .

La señora Elizabeth María Cruz Martínez ${ }^{10}$ recuerda que las cajas:

Por lo que me contaba mi papá ${ }^{11}$, esas vienen de Bolivia. Que el abuelito y la abuelita venían de allá y las trajeron en unas puruñas, que son unos cántaros envueltos en aguayos en los burros. Ahí los manejaba mi abuelo ${ }^{12}$.

La señora Venancia Cruz señala que los santitos:

Los trajo el abuelo Lucas de Bolivia. De allá de donde era él de Quetena. Él en su juventud, en su niñez tenía sus imágenes y dijo sabe qué yo me voy a trabajar a Chile y allá sus padres le dijeron sabe qué te vas, te llevas tus santos. Y de allá, él trajo sus imágenes, sus santos ${ }^{13}$.
Quetena, localidad situada en el altiplano meridional de Lípez, se configura, en estas memorias familiares, como el punto de partida de la circulación de las cajitas de madera de San Antonio de Padua a Ojos de San Pedro. Y estos son los cajones llameritos asociados a la producción del ganado, y también llamados cajones viajeros o San Antonio viajeros, por su tamaño reducido (Walter Sánchez, comunicación personal, 2018).

Cuando los San Antonio viajeros llegaron a Ojos de San Pedro había una laguna grande. Recuerda la señora Ana Lobera Ramos que era muy bonita, poblada de aves, patos y taguas, y la gente del lugar sacaba gran cantidad de huevos de taguas. También había tropas de llamas, vicuñas, burros y burros salvajes. Y eran los cajones portátiles de San Antonio de Padua los que estaban relacionados con la crianza de los burros y llamas, su conservación y no pérdida. Las familias celebraban a San Antonio de Padua, se bailaba al son de quenas, los días 12, 13 y 14 de junio. Las cajitas se sacaban en procesión, primero desde las casas, hasta que el abuelo Lucas construyó una pequeña capilla, y cuando la iglesia estuvo en pie, se sacaban desde allí, lugar donde también estaba un santo grande, el que hoy día está en la iglesia grande de San Pedro Estación, el que a comienzos de la década de 1950 , fue regalado por el sacerdote jesuita de apellido Salas, quien llevó la imagen a la iglesia de Ojos de San Pedro ${ }^{14}$.

\section{Circulaciones de Memorias entre Quetena, Ojos de San Pedro y San Pedro Estación}

La señora Venancia Cruz recuerda que ella, junto a su abuelito don Lucas Cruz Vilca, desde Ojos de San Pedro, iban en burro a Quetena, transponiendo la cuenca del Río San Pedro, atravesando las vegas de Inacaliri, para llegar al río "Siloli y luego Laguna Colorada"15, lugar muy significativo pues ella cuenta que allí se detenían para buscar huevos de parina. Al respecto se señala que no solo se traían huevos de parina, sino que también:

enterita la parina para las plumas. En ese tiempo usaban mucho para los pagos, dependía del yatirí -que le llamamos-cuáles son las plumitas que necesitaban: hay unas coloraítas, unas negras, unas blanquitas y unas rosaditas (Bernardo Berna Pérez [1947, nacido en Turi] en Manríquez 2017:47).

Respecto de la importancia de las plumas de parina, en contextos ceremoniales, se reconoce que "También venían de Bolivia -de Laguna Coloradatraían a vender huevos y plumas de parina, mis 
papás compraban plumas para hacer floramientos: la coloradota porque esa se usan para hacer huaqui" (Alberto Panire Palalo [1931, Ayquina] en Manríquez 2017:57).

El ingeniero y geógrafo Alejandro Bertrand recorrió en 1884 el Río Quetena y las localidades de Quetena Grande y Quetena Chica, observando que:

Divisamos las habitaciones de Quetena Chica, diseminadas en diversas laderas que rodean las ciénagas i vegas de este nombre [...]. Desgraciadamente no había nadie en la localidad [...]; la familia Esquivel, ricos propietarios de rebaños, se hallaba diseminada, unos en Guari, otros en Quetena Grande [...]. El 19 pasamos, a las tres leguas de nuestro campamento, por las estensas vegas de Quetena Grande, donde pacen las numerosas llamas i mulas de los Esquivel (Bertrand 1885:71-72).

Antes de acceder a Quetena Chica y Grande se encontraron con:

varios ranchos, todos desiertos, agrupados en torno de un oratorio o santuario. Penetramos en este último por una que mas parecía ventana que puerta; había allí un crucifijo pintado en un trocito de tabla i envuelto en un lienzo de lana de llama, varios huevos de parina colgados del techo i un bastón de madera. En un tiestecito de barro hallamos resina de yareta destinada sin duda a desempeñar el oficio de incienso. El vallecito i la localidad se llamaban Maicocueva; vense pastorear por los alrededores numerosos rebaños de llamas (Bertrand 1885:70).

La vinculación de Sud-Lípez con la Cuenca San Pedro-Inacaliri también se observa en otros contextos de los siglos XIX y XX, donde se registran movimientos migratorios, de poblaciones pastoras, desde el sur-este de Lípez hacia la cuenca. Lo que también se observa para las décadas de 1920, 1930 y 1940, siendo estos movimientos una continuidad de prácticas económicas asociadas al uso de pastos y vegas de la Cuenca San PedroInacaliri, como también gatillados por la demanda de mano de obra para la minería regional asociada a la yareta utilizada como combustible (Martínez 1985).

La Cuenca de San Pedro-Inacaliri era un espacio, en cuyas cordilleras, el recurso abundaba, el cual era extraído y secado, sobre los $3.000 \mathrm{msm}$, y conducido, a lomo de animal o camión, a San Pedro Estación, lugar de acopio y traslado, vía el ferrocarril, hacia
Chuquicamata y Calama. Fue la Chile Exploration la que en el año 1925 logró la concesión de la explotación de la yareta de las cordilleras al interior de Estación San Pedro, y la familia Urdangarin, particularmente los hermanos Miguel, Ignacio y Cándido, fueron, en una primera etapa, sus contratistas y administradores. En una segunda etapa, fue don Miguel, junto a sus hijos, los encargados de esa concesión hasta, aproximadamente, 1961, fecha en que paralizó todo, ya que el gobierno prohibió explotar la yareta:

la cordillera a la altura de Estación San Pedro, toda esa zona tenía yareta. La yareta aparece a los tres mil, cuatro mil metros. Los trabajadores de mi papá los llevaban en el camión, estaban todo el día, cargaban el camión con la yareta y volvían. Hasta ahí llegaban al ferrocarril, teníamos un ramal particular nosotros. Cuando teníamos suficiente yareta, se cargaba esos vagones y se venían a Chuquicamata. Antes allí solo se usaba yareta, hasta que se fue agotando y ahí apareció el gas licuado. A la gente se le pagaba por día y también por tratos, generalmente trabajaban a tratos. Les resultada más económico. En la cordillera misma cuando se extraía yareta de los cerros arriba, ahí se cargaban llamas, bajaban las llamas y ahí se ponían en los camiones. Era caro construir caminos en ese tiempo ${ }^{16}$.

El trabajo del corte de la yareta era extremadamente delicado. Se requería de chuzo, con punta de paleta o de hacha. El patrón pagaba por mata de yareta. Los que la cortaban tenían que levantarse a las tres de la mañana, puesto que a esa hora la raíz se cortaba fácil, a esa hora era como un elástico. Como estaba verde, había que dejarla secar ya sea en el cerro o en los canchones de Estación San Pedro ${ }^{17}$.

Eran poblaciones indígenas del sur-este de Lípez, entre otras, las encargadas de su traslado, hasta por lo menos, la década de 1940, cuando ya el camión se introduce completamente en la zona, privilegiándose como medio de transporte, lo que puso en crisis a la arriería a lomo de animal desarrollada por familias del sur-este de Lípez (Richard et al. 2016).

Se recuerda que por esos años, en Estación San Pedro habían muchas familias, muchas de ellas vinculadas con el trabajo del ferrocarril, con las tareas de corte y traslado de la yareta, además del trabajo en azufreras cercanas, todo lo cual se apilaba en canchones en la localidad. Se señala que en esos años también había una pulpería:

No se usaba dinero, libretas. Ahí se anotaba lo que iba a comprar la persona. Y a fin de mes se 
hacia la liquidación de lo que había comprado, con lo que había ganado. Los dueños de la pulpería eramos nosotros, traíamos las cosas de Calama, harina. Ellos hacían su pan, había hornos. Había trabajadores indígenas de Bolivia. La gente del poblado era de Ollagüe, Ascotan, Conchi, hay dos Conchi, viejo y nuevo. También iban trabajadores de Calama. Trabajaban con hachas, chuzo y de repente se usaban explosivos ${ }^{18}$.

La vinculación de Sur Lípez, a través de Quetena, con la Cuenca San Pedro-Inacaliri, particularmente con Ojos de San Pedro y Estación San Pedro no solo tiene una historicidad que data de tiempos subactuales, sino que se inserta en una movilidad distinguible también en tiempos coloniales, particularmente en el siglo XVII, de poblaciones lipes a localidades de Atacama la Baja, asociada no solo al acceso a espacios situados a distancia, y que por ende permitían complementar economías (Martínez 1998). También esos accesos estaban asociados con una historicidad mayor, desde el 900 DC, de prácticas "de la movilidad poblacional interregional [...] [entre] esta subregión del Alto Loa con la zona altiplánica meridional boliviana, específicamente con las cuencas hidrográficas de Lípez y Quetena" (Castro y Varela 2000:832). La localidad de Quetena, espacio caracterizado por asentamientos de data prehispánica, estaba habitado por "poblaciones dispersas, especializadas en el pastoreo de camélidos, la caza, la recolección y el tráfico de caravanas de larga distancia" (Nielsen 2002:182). Y aún en los siglos XIX y XX formaba parte de una activa red de arrieraje que "vincula a los habitantes de una zona bastante extensa: los territorios de Sud-Lípez y Sud-Chichas, en Bolivia; el noroeste argentino -Tucumán-; y la región Atacameña [...] vemos a distintas unidades familiares relacionándose mutuamente, ya sea por matrimonios o porque parecieran compartir recursos y espacios" (Martínez 1998:16). A su vez, se reconoce que ya en la década de 1879 sería posible distinguir la presencia de familias de Quetena en el área (Martínez 1998:18).

Los santos llegaron a Ojos de San Pedro, "un espacio 'lleno', repleto de significación, que existe y donde es posible existir; un espacio humanizado y hecho real por el tratamiento lingüístico" (Martínez 1976:265). Una estancia llamado Ojos, en las cercanías de los volcanes San Pedro y San Pablo. Surge la pregunta si este ojo de agua y sus volcanes podrían tratarse, dentro de las categorías de pensamiento andino, de un uywiri-cerro, es decir, una entidad, donde los ojos podrían ser los ojos de los volcanes, "los que tienen que ver con la suerte en general del hombre; especialmente con la salud, pero también con el buen éxito de los negocios, en los viajes, en la vida familiar" (Martínez 1976:267) ¿Podrían pensarse las cajas como las guardianas de la suerte o bien que ellas guardan la suerte familiar? A su vez, los Ojos son "juturi, un agujero sagrado del cual depende el "multiplico de ganado"" (Martínez 1976:267). Si los pastores de llamas, burros y mulas de las vegas de Ojos de San Pedro tenían estos animales que se criaban, que eran uywa ¿Podrían estar asociadas las cajas de San Antonio a esos uywas o animales criados, y a las acciones que se requerían para protegerlos, para que se multiplicaran y crecieran y no se perdieran?

Algunas cajas de santos tienen en su interior unas piedras, las que se conocen como piedras santos. Estas piedras santos han sido asociadas a las conopas, algunas de ellas tienen forma de animales, reconociéndose su vinculación con una larga tradición prehispánica (Sánchez y Gracia 2013; Oros 2015). Siendo estas piedras objetos predilectos destruidos por los extirpadores de idolatrías en los Andes a comienzos del siglo XVII:

Las Conopas son propiamente sus dioses [...] Lares y Penates [...] son algunas piedras particulares, y pequeñas [...]. Y aconteçe algunas vezes (y no son pocas las q[ue] se han topado de estas) q[ue] q[u]ando algún Indio, o India se halló a caso alguna piedra de esta suerte, o cosa semejante en $\mathrm{q}[\mathrm{ue}]$ reparo, va al Hechizero, y le dize Padre Mio, esto he hallado, que será? y el le dize con grande admiración, esta es Conopa, reveré[n]ciala, y mochala con grande cuidado, que tendrás mucha comida y grande descanso (Arriaga 1621:14-15).

Se reconoce que las conopas forman parte, a ojos hispanos, de un complejo particular en el ámbito de la cosmovisión andina:

[...] que Conopa o Chanca tiene, qu[e] es su dios Penate, y si es Mucui Conopa, o Zara Conopa, o Llama Conopa, si es Conopa del maíz, o del Ganado, y si todos los demás Indios las tienen, lo cual es cosa certisima, y en que se á instar mucho, porque se á experimentado, que mas fácilmente descubran las Huacas comunes que las particulares que cada uno tiene (Arriaga 1621:90).

Luego es posible pensar a las conopas como entidades, como existentes adorados en el contexto de los ayllus y asociados a actividades agrícolas y 
ganaderas, contando con nombres particulares para cada una de ellas. Y en el contexto de la extirpación de las idolatrías fueron considerados objetos que debían ser destruidos o derribados del corazón de las gentes indias, al igual que los qeros, las aquillas, los mates, las camisetas de cumbi, la coca, los tambores, los caracoles, las momias, las ollas, los cántaros, en suma todos los objetos que se utilizaban para la memoria de las guacas, para reverenciarlas, y darles de comer y de beber (Arriaga 1621:98).

De acuerdo a Viviana Manríquez, las conopas se adscriben a la categoría de yllas, término quechua que refiere "al prodigar poder, abundancia, riqueza, protección a la vez que significa guardar cosas preciadas, atesorar lo antiguo, conexión con los antepasados (Manríquez 1999:114). Y que ello tendría una expresión material, en este caso las conopas:

Son objeto de 'adoración' como las guacas y eran heredadas de padres a hijos siendo utilizadas en el ritmo íntimo de cada familia [...] Como proveedoras de 'ventura y riqueza' eran a su vez atesoradas y pasaban de generación en generación para proveer de protección a la unidad doméstica y a las acciones que sus miembros emprendían (Manríquez 1999:109).

Se ha reconocido que las piedras de los cajoncitos de santos estaban asociadas a rezos y cantos, rezos que eran y son cantados y "que funcionan como peticiones de lluvia” (Castro y García 2017:2). No existen indicios que den cuenta si los cajones de San Antonio de Padua que llegaron de Quetena tenían o no piedras santos en su interior, las que generalmente se ubican detrás del santo. Posiblemente y si es que hubiesen tenido piedras santos, estas se perdieron, quizás en las circulaciones de las cajas, perdiéndose también la tradición o la memoria de los rezos y cantos que las hacían funcionar.

\section{A Modo de Conclusión}

Las cajas de madera de San Antonio de Padua y sus circulaciones son testimonios de un trozo de la historia de la ocupación de la Cuenca de San PedroInacaliri, guardando biografías en las que se puede observar, como en una vida, una gran variedad de índices o fragmentos de vidas sociales.

Cada 13 de junio, el día grande de la fiesta de San Antonio, cuando las cajas de madera salen a caminar en andas, por el poblado de San Pedro Estación, las cajas tienen un ser, una presencia en la vida social e histórica de la comunidad. Son objetos que siguen siendo objetos vivos y es eso justamente lo que los aleja de ser ruinas, puesto que las cajas de madera no han salido de la circulación (Menard 2016) (Figuras 14 y 15).

A partir de este trabajo se evidencia que el acercamiento a las cajas de madera, a partir de sus circulaciones, desplazamientos y trayectorias permite reconocer que ellas están llenas de vitalidad o de vida. Junto con identificarlas como integrantes de flujos que ponen en relación lugares, memorias sociales y transmisiones orales. Lo que a su vez permite pensar que los diferentes accesos a las vidas sociales de las cajas, dan cuenta de las sucesivas reinscripciones en una multiplicidad de temporalidades históricas.

Si estas manufacturas imbrican muchos ámbitos de la experiencia de las gentes indias,

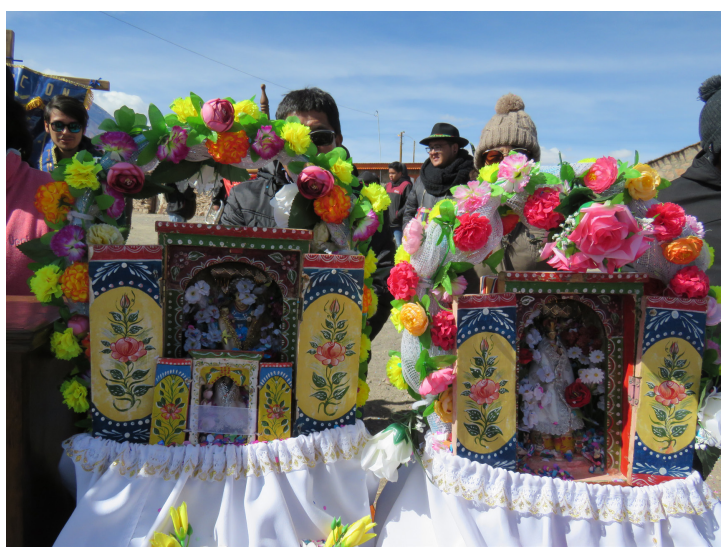

Figura 14. Las cajas de santos en el día grande de la fiesta. Fotografía de Carolina Odone, junio 2018.

The boxes of saints on the big day of the celebration. Photograph by Carolina Odone, June 2018.

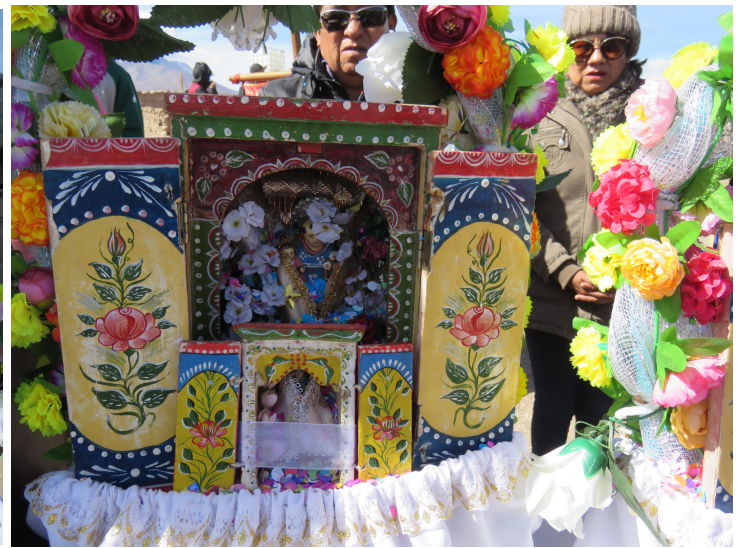

Figura 15. Las cajas de santos en el día grande de la fiesta. Fotografía de Carolina Odone, junio 2018.

The boxes of saints on the big day of the celebration. Photograph by Carolina Odone, June 2018. 
en tanto sujetos históricos colectivos, a su vez, contienen cambios, continuidades y permanencias de sus mundos sociales. Permitían y permiten, mantener los vínculos familiares y parentales, las interacciones sociales, que sus historias y memorias no sean olvidadas y que los habitantes dispersos de la localidad de San Pedro Estación sigan encontrándose cada 13 de junio, en el día grande de la fiesta de San Antonio de Padua (Figura 16).

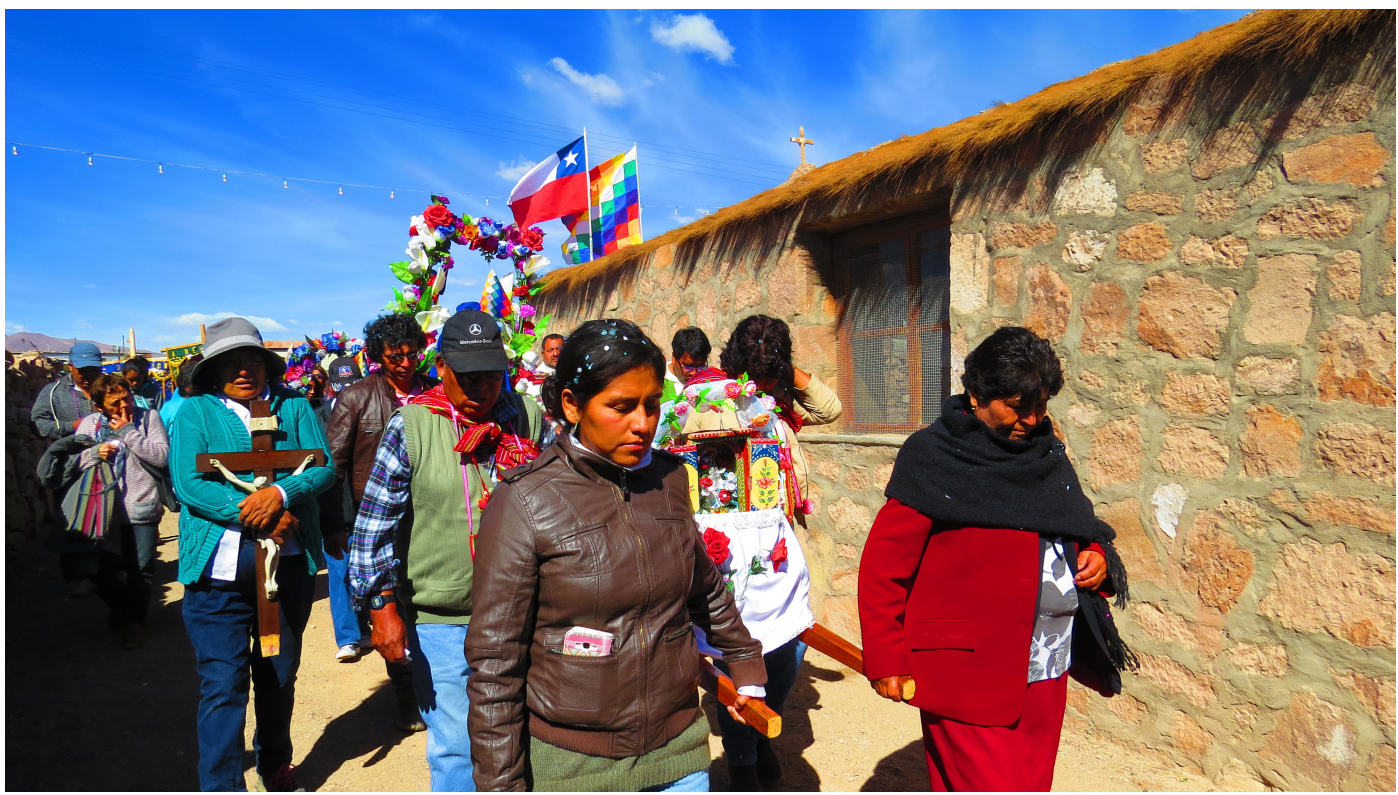

Figura 16. Las cajas de santos en andas. Fotografía de Carolina Odone, junio 2018.

The boxes of saints "en andas". Photograph by Carolina Odone, June 2018.

Las cajas de madera de San Pedro Estación presentan indicios de retoques ya sea en los arreglos de las puertitas o en los retoques de pintura, reparaciones que expresan su valor social y dan cuenta de desempeños colectivos, ligados por ende al autoreconocimiento y al compromiso de las personas. Por ello, las cajas de madera, las urnas como se les llama en San Pedro Estación, no son cosas sino que objetos en constante construcción identitaria.

Las cajas son respetadas y queridas por las gentes indígenas que habitaron y habitan las tierras altas. Los objetos se limpian, se encreman, para la celebración de la fiesta del patrono del pueblo. Se colocan en andas para que vean el pueblo y salgan a caminar junto a los comunarios, los asistentes y visitantes (Figura 17). Son objetos que aún siguen animando sus vidas y de los que se han ido (Figura 18). Las cajas de madera se guardan en las iglesias cuando ya no pueden ser bien cuidadas por sus dueños. Incluso se ha detectado, para la localidad de Quetena Chico, que cuando las cajas de santos quedan sin dueños, ellas se "consumen", como refiere el catequista Aurelio Berna de la iglesia de Quetena Chica quien recuerda que su abuelito Emilio Esquivel llevo su caja de San Santiago, que tenía guardada en su capilla, trasladándola a Uyini para que un santero la convirtiera en cenizas (Comunicación personal, diciembre 2018) (Figuras 19 y 20). Todo ello permite también pensar que las cajas de madera dan cuenta de recepciones andinas del cristianismo desde creaciones/agencias/ intervenciones individuales, familiares y colectivas.

También considero que las cajas de madera pueden ser pensadas como objetos que contienen un valor. Cuando las cajas vivían en la iglesia de Ojos de San Pedro, ellas tenían un vínculo con la crianza de llamas y burros, permitiendo su reproducción, conservación y no perdida. Las cajas de San Antonio guardaban esa suerte, al mismo tiempo que la cuidaban, estimulando la prosperidad y bienestar para que a las familias les fuese bien. Además se ubicaban en un lugar físico, en un paisaje natural, en los ojos de San Pedro que era un agujero 'creacional', vinculado con el agua y con el volcán San Pedro, un juturi que en el espacio emergía como un lugar también cosmológico donde habitaban los seres guardianes de manantiales y animales, beneficiando la cría de los 


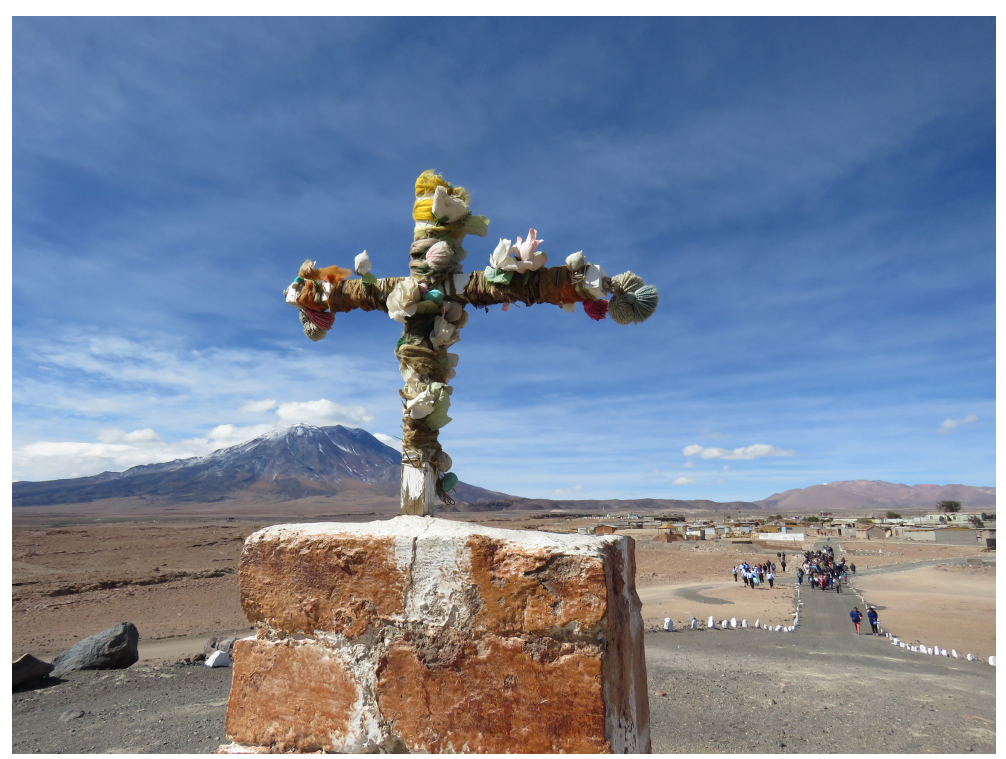

Figura 17. Vista de la procesión en el día grande de la fiesta. Fotografía de Carolina Odone, junio 2018. View of the procession on the big day of celebration. Photograph by Carolina Odone, June 2018.

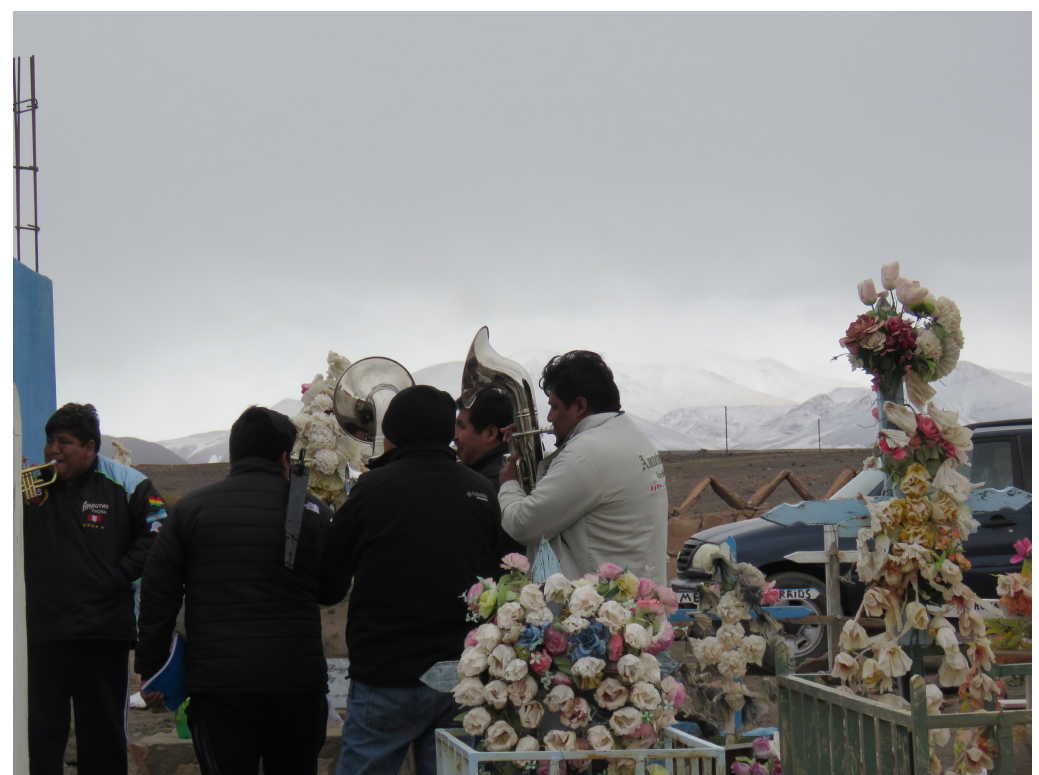

Figura 18. Para los que ya no están, desde el cementerio de San Pedro Estación. Fotografía de Carolina Odone, junio 2018.

For those who are no longer there, from the cemetery of San Pedro Estación. Photograph by Carolina Odone, June 2018.

rebaños, y su multiplicación. Lo que también permitiría pensar que esos ojos de San Pedro formarían parte de la genealogía de paqarinas u orificios de la tierra donde salieron ancestros en los pasados prehispánicos en la Cuenca San Pedro-Inacaliri.

A su vez, las cajas de madera y sus circulaciones dejan ver vínculos con las rutas de caravaneros/ llameros antiguos, con la explotación de la yareta y los viajes de su transporte, con los cambios que introdujo el ferrocarril, con los nuevos usos del agua, con las migraciones forzosas, con las nuevas ritualidades cristiana-católicas, donde los cajones de San Antonio siguen ocupando un lugar de relevancia, y aunque hoy existen relaciones 


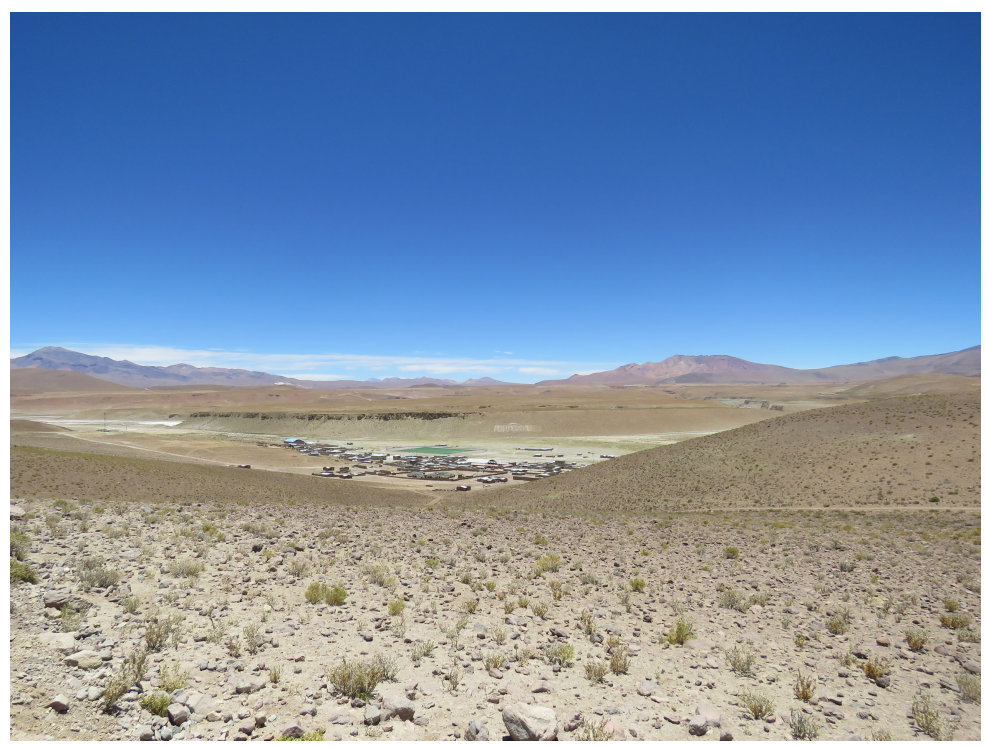

Figura 19. Vista de la localidad de Quetena Chica, Sur-Lípez. Fotografía de Carolina Odone, diciembre 2018.

View of Quetena Chica, Sur-Lipez. Photograph by Carolina Odone, December 2018.

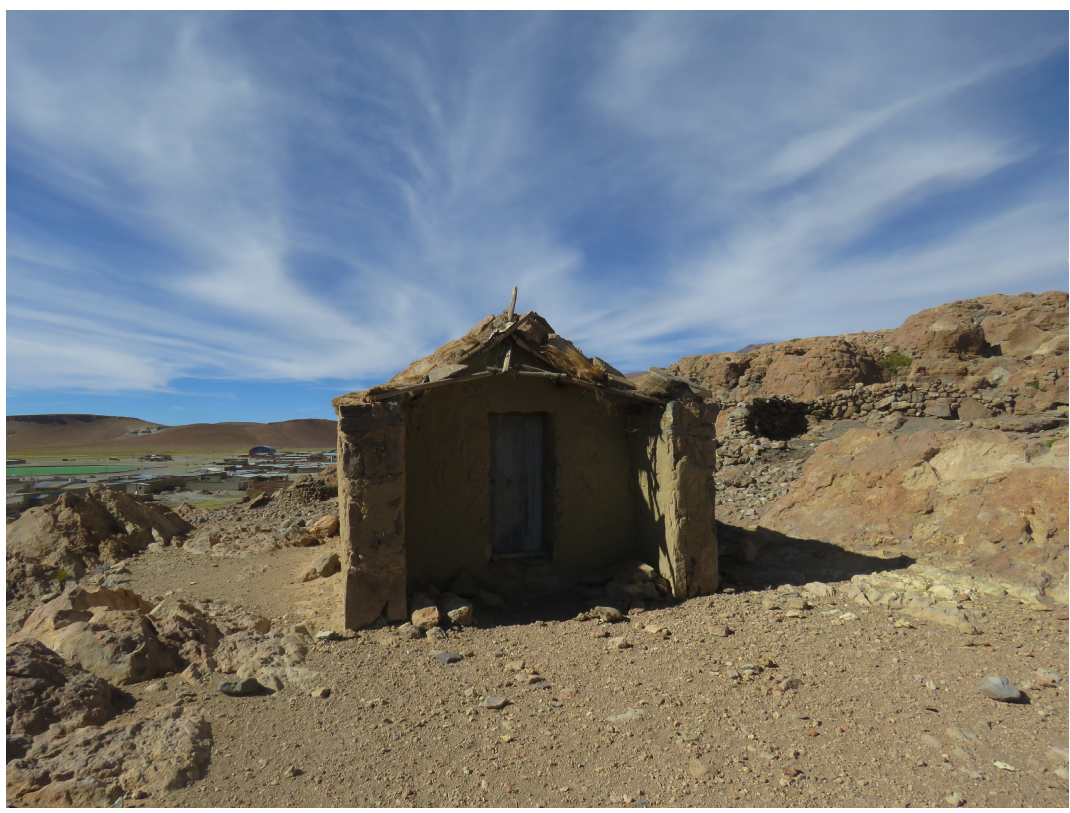

Figura 20. La capilla de don Emilio Esquivel en Quetena Chica, Sur-Lípez. Fotografía de Carolina Odone, diciembre 2018.

The Chapel of don Miguel Esquivel, Quetena Chica, Sur-Lipez. Photograph by Carolina Odone, December 2018.

desaparecidas, aún son valiosos reuniendo en ellas vínculos intangibles. Es que las cajas de San Antonio no están muertas, son objetos vivos que actúan en el mundo de los vivos manteniendo relaciones significativas con los circuitos de las memorias, del pasado y también el presente. Son objetos valiosos, objetos antiguos, una suerte de nuevas illas resignificadas. 
Agradecimientos: Mis agradecimientos a CONICYT-FONDECYT por el financiamiento del proyecto posdoctoral $\mathrm{N}^{\circ} 3160256$, al Instituto de Historia de la Pontificia Universidad Católica de Chile, y al investigador patrocinante, el historiador Jaime Valenzuela M. A todos ellos mis reconocimientos por el espacio de trabajo, la atención y el patrocinio dado a mi proyecto. Mis agradecimientos a Valentina Acuña, Juan Francisco Echeverría y Fernando Candia, ayudantes de investigación que me acompañaron durante la ejecución del proyecto. Mi inmensa gratitud a los habitantes de San Pedro Estación, de manera especial a Miguelina Ramos Cruz, quien siempre me abrió las puertas de su casa y de su memoria. Igualmente mi reconocimiento a don Olegario Carales y su señora Ana Lobera, a la señora Irma Choque, a la señora Venancia Cruz, a la señora Simona Bautista Ayavire, a la señora Elizabeth Cruz Martínez, y al señor Humberto Urdangarín. Gracias a todos y todas por permitir que conociera las cajas de santos desde sus recuerdos y memorias. Mis agradecimientos a los evaluadores por sus revisiones acuciosas y los comentarios agudos y sugerentes, los que me permitieron mirar nuevamente los datos, las descripciones, y las memorias y sus circuitos.

\section{Referencias Citadas}

\section{Fuentes inéditas}

Archivo Nacional de la Administración [ARNAD], Archivo Nacional de Chile:

Ministerios y Servicios Públicos, Ministerio de Obras Públicas. v. $2464,1912$.

Ministerios y Servicios Públicos, Ministerio de Obras Públicas. 'Memoria esplicativa', 1913 [1912], v. 2535.

Ministerios y Servicios Públicos, Ministerio de Obras Públicas, 1918, v. 2876.

\section{Fuentes secundarias y bibliografía especializada}

Abercrombie, T. 2006 [1998]. Caminos de la Memoria y el Poder. Etnografía e Historia de una Comunidad Andina. Sierpe Publicaciones, La Paz.

Academia Mayor de la Lengua Quechua 2005. Diccionario Quechua-Español-Quechua. Gobierno Regional, Cusco.

Aldunate, C. 1984. Desecación de las vegas de Turi. Chungara 14:135-139.

Arguedas, J.M. 1998. Notas elementales sobre el arte popular religioso y la cultura mestiza de Huamanga. En Formación de una Cultura Nacional Indoamericana, editado por J.M., Arguedas, pp. 148-172. Siglo Veintiuno Editores, México D.F.

Appadurai, A. 1991. La Vida Social de las Cosas. Perspectiva Cultural de las Mercancías. Consejo Nacional para la Cultura y las Artes, México D.F.

Arriaga, P. de. 1621. Extirpación de la Idolatría del Piru. Impresor de libros Gerónimo Contreras, Lima.

Baudrillard, J. 1969. El Sistema de los Objetos. Siglo Veintiuno Editores, México D.F.

Bertrand, A. 1885. Memoria sobre Las Cordilleras del Desierto de Atacama i Rejiones Limítrofes. Imprenta Nacional, Santiago.

Bugallo, L. 2010. La estética de la crianza. Los santos protectores del ganado en la Puna de Jujuy. En Arte indígena. Categorías, Prácticas, Objetos, coordinado por M. Alba y M. Penhos, pp. 85-102. Encuentro Grupo Editor, Córdoba.

Correa, L. 2013. Del poder a los tratados: Desarrollo y ferrocarriles en Bolivia, 1870-1904. Historia 46:315-341.
Castro, V. y V. Varela 2000. Los caminos del 'reiinka' en la región del Loa Superior. Desde la etnografía a la arqueología. Actas del XIC Congreso Nacional de Arqueología, pp. 815839. Sociedad Chilena de Arqueología, Copiapó.

Castro, N. 2008. Y le tuviesen por santo: Caminos de la devoción indígena colonial (Audiencia de Charcas, 1708). Diálogo Andino 31:7-29.

Castro, N. 2013. Religiosidad local y devoción indígena en el ciclo Borbónico (Arzobispado de La Plata, 1750-1808). Allpanchis XLIV (81-82):197-244.

Castro, D. y A. García 2017. Pascua, Rezos y Llut'asqas de las Comunidades de Vitichi y Puna de Potosí. Instituto de Investigaciones Antropológicas y Museo Arqueológico de la Universidad Mayor de San Simón (INIAM-UMSS), Cochabamba.

Corrales Gaitán, A. 1998. Ermitas Cacerenses. Cámara Oficial del Comercio e Industria de Cáceres; Cáceres.

Chávez, F. 2004. 'Conmigo vas a trabajar': sueño iniciático entre las parteras andinas de Piura, Perú. Dimensión Antropológica 12 (32):69-87

Choque, L., J. Mamani, M. Mamani y R. Moreno 2008. Informe Monografía Reconstrucción histórica del pueblo de San Pedro Estación. Manuscrito en poder del autor.

Dean, C. y D. Leibsohn 2003. Hybridity and its Discontents: Considering Visual Culture in Colonial Spanish America. Colonial Latin American Review 12 (1):5-35.

Del Solar, M.E. 1992. Cajón San Marcos. En El Retablo Ayacuchano. Un Arte de los Andes, pp. 17-26. Instituto de Estudios Peruanos, Lima.

Diccionario Quecha-Español 2005. Academia Mayor de la Lengua Quechua, Cusco.

Espinoza, E.1897. Jeografía Descriptiva de la República de Chile. Imprenta i encuadernación Barcelona, Santiago.

Garcés, F. y W. Sánchez 2016. Inscripciones y escrituras andinas. Un sistema complejo y denso de visualidades, oralidades y espacialidades. Boletín del Museo Chileno de Arte Precolombino 21 (1):115-128

Gell, A. 1998. Art and Agency: An Anthropological Theory. Clarendon, Oxford

Gentile, M. 2013. Expresiones populares de la devoción a San Antonio de Padua en la República Argentina, siglos XX y XXI. En El Patrimonio Inmaterial de la Cultura Cristiana, coordinado 
por F.J. Campos y Fernández de Sevilla, pp. 861-878. Ediciones Escurialenses, Madrid.

Golte, J y R. Pajuelo (eds.) 2012. Universos de Memoria. Aproximaciones a los Retablos de Edilberto Jiménez sobre la Violencia Política. Instituto de Estudios Peruanos, Lima.

González, J.A. 2008. La conquista de una frontera. Mentalidades y tecnologías en las vías de comunicación en el desierto de Atacama. Revista de Geografía Norte Grande 40:23-46.

Gonzalez, R. 2003. Imágenes de Dos Mundos: La Imaginería Cristiana en la Puna de Jujuy. Fundación Espigas, Buenos Aires.

González, S. 2011. Las históricas relaciones entre Tarapacá y Oruro: la frustrada tentativa de integración transfronteriza durante el ciclo de expansión del salitre (1864-1928). Revista de Geografía Norte Grande 50:63-85.

Gutiérrez, R. 1995. Pintura, Escultura y Artes Útiles en Iberoamérica, 1500-1825. Ediciones Cátedra, Madrid.

Hoskins, J. 2006. Agency, biography and objects. En Handbook of Material Culture, editado por C. Tilley, W. Keane, S. Müchler, M. Rowlands, y P. Spyer, pp. 74-84. SAGA Publications, London.

Kennedy, A. 1998. Circuitos artísticos interregionales: de Quito a Chile. Historia 31:87-111.

Latour, B. 2008. Reensamblar lo Social. Una Introducción a la Teoría del Actor-Red. Manantial, Buenos Aires.

Macera, P. 1981. Retablos andinos. Historia y Cultura 4:1-26.

Macera, P. 1982. Los retablos andinos y don Joaquín Lopez Antay. Boletín de Lima 19:15-35.

Magaña, E. 1997. Entrevista realizada por Peter Mason en la Residencia de Estudiantes. Madrid, 30 de septiembre de 1997. Manuscrito en poder del autor.

Manríquez, V. 1999. El término Ylla y su potencial simbólico en el Tawantinsuyu. Una reflexión acerca de la presencia inca en Caspana (río Loa, desierto de Atacama). Estudios Atacameños 18:107-118.

Manríquez, V. 2017 Así Era la Vida Antes. Nosotros así Pasábamos. Edición y entrevistas. Pehuén Editores, Santiago.

Martínez, G. 1976. El sistema de los uywiris en Isluga. En Separata del Tomo de Homenaje al R.P. Gustavo Le Paige, pp. 255-327. Universidad del Norte, Antofagasta.

Martínez, J.L. 1985. La formación del actual pueblo de Toconce (siglo XIX). Chungara Revista de Antropología Chilena 15:99-124.

Martínez, J.L. 1998. Pueblos del Chañar y del Algarrobo. Centro de Investigaciones Diego Barros Arana, Facultad de Filosofía y Humanidades, Universidad de Chile, Santiago.

Menard, A. 2016. Cachureos, reliquias, mercancías, monumentos. Vida y vitalidad de los fetiches en la era de la patrimonialización. Conferencia presentada el 2016 en Arica en el contexto de los Coloquios regionales El Patrimonio ¿Bien común o Bien de mercado? Consejo Nacional de la Cultura y las Artes. Disponible en http://coloquiospatrimoniales.cultura. gob.cl/repositorio/

Miller, D. 2005. Materialidad: una introducción. En Materiality, editado por D. Miller, pp. 1-50. Duke University Press, Durham.

Nielsen, A. 2002. Asentamientos, conflictos y cambio social en el altiplano de Lípez (Potosí). Revista Española de Antropología Americana 32:179-205.

Odone, C. 2018. Iniciando el recorrido de las cajas con sus Santolines. Miradas desde San Pedro Estación (Cuenca San
Pedro-Inacaliri, II Región, Antofagasta). Ponencia presentada en la XXXI Reunión Anual de Etnología (RAE), organizada por el Museo Nacional de Etnografía y Folkore, pp. 171-182. MUSEF, La Paz.

Odone, C. 2019. Trazas de memorias desde dos cajas de madera de San Antonio de Padua en la iglesia y capilla de San Pedro Estación (Cuenca San Pedro-Inacaliri, II Región, Chile, siglos XIX y XX). En Circulación de Creencias. Itinerari, Pratiche e Limiti della Trasmissione Religiosa in Europa e nel Nuovo Mondo, Universidad Roma Tre, Universidad de Chile y Pontificia Universidad Católica de Chile. En prensa.

Oros, V. 2015. Retablos y Piedras Santos. La Materialidades de las Wak'as. Museo Nacional de Etnografía y Folklore, La Paz.

Querejazu, P. 1995. La escultura en el Virreinato del Perú y la Audiencia de Charcas. En Pintura, Escultura y Artes Útiles en Iberoamérica, 1500-1800, coordinado por R. Gutiérrez, pp. 257-270. Ediciones Cátedra, Madrid.

Quijada, F. 2018. Arte popular religioso de las culturas surandinas. Colección MAPA, Universidad de Chile. En Catálogo Religiosidad Popular, pp. 34-49. Museo de Arte Popular Americano Tomás Lago, MAPA, Facultad de Artes, Universidad de Chile, Santiago.

Richard, N., J. Moraga y A. Saavedra 2016. El camión en la puna de Atacama (1930-1980). Mecánica, espacios y saberes en torno a un objeto técnico liminal. Estudios Atacameños 52:89-111.

Sánchez, G. y L. Gracia 2013. Cajones. Arte Populary Memoria Religiosa. Instituto de Investigaciones Antropológicas y Museo Arqueológico de la Universidad Mayor de San Simón (INIAM-UMSS), Cochabamba.

Sánchez, W. 2015. El cajón ritual-religioso campesino: entre lo global y lo local. En Textualidades entre Cajones, Textiles, Cueros, Papeles y Barro, editado por F. Garcés y W. Sánchez C., pp. 7-38. Instituto de Investigaciones Antropológicas y Museo Arqueológico de la Universidad Mayor de San Simón (INIAM-UMSS), Cochabamba.

Sanhueza, C. 2011. Atacama y Lípez. Breve historia de una ruta: escenarios históricos, estrategias indígenas y ritualidad andina. En En Ruta. Arqueología, Historia y Etnografía del Tráfico Sur Andino, editado por L. Núñez y A. Nielsen, pp. 313-340. Encuentro Grupo Editor, Córdoba.

Sillar, B., 2009. The social agency of things? Animism and materiality in the Andes. Cambridge Archaelogical Journal 19 (3):367-377

Schenone, H. 1992. Iconografía del Arte Colonial, T. I y II. Fundación Tarea, Buenos Aires.

Taylor, D. y M. Fuentes (eds.) 2011. Estudios Avanzados de Performance. Fondo de Cultura Económica, México D.F.

Thomas, N. 1991. Entangled Objects. Exchange, Material Culture, and Colonialism in the Pacific. Harvard University Press, Cambridge.

Ulfe, M.E. 2004. El arte de los retablos ayacuchanos. Religiosidad popular, historia y práctica cultural emergente. Allpanchis 64:73-99.

Ulfe, M.E. 2011. Cajones de la Memoria. La Historia Reciente del Perú a Través de los Retablos Andinos. Pontificia Universidad Católica del Perú, Lima.

Valenzuela, A. 2006. Atacameños de Calama. Diversidad, Transitoriedad y Fragmentación en las Organizaciones Atacameñas Urbanas y su Relación con el Estado Chileno. 
Tesis para optar al grado de Maestra en Antropología Social, Centro de Investigaciones y Estudios Superiores en Antropología Social (CIESAS), Guadalajara, México D.F.

Valenzuela, J. 2016. ... que las ymagenes son los ydolos de los christianos. Imágenes y reliquias en la cristianización del
Perú (1569-1649). Jahrbuch für Geschichte Lateinamerikas 43:41-65.

Yañez, N y R. Molina 2008. La Gran Minería y los Derechos Indígenas en el Norte de Chile. LOM Ediciones, Santiago.

\section{Notas}

${ }^{1}$ No se cuenta con datos que permitan reconocer otras apariciones de San Antonio de Padua en el área de estudio.

${ }^{2}$ Es sumamente interesante la actual discusión de la decoración de flores en las puertas postulándose que constituirían la firma de sus artesanos. En las puertas de estos objetos, el creador dejó plasmada en el tipo, diseño y colores de las flores, la identificación de su taller (comunicación personal, Rosaura Andazabal, 2018).

${ }^{3}$ Entrevista realizada en San Pedro Estación en junio de 2017.

${ }^{4}$ La señora Irma Choque, hija de doña Victoria Huaca, es quien relata este conocimiento. La entrevista fue realizada en Calama en junio de 2017.

5 Entrevista realizada en Calama en junio de 2017.

${ }^{6}$ Nacido en 1943 en San Pedro Estación. Entrevista realizada en Calama en junio de 2016.

${ }^{7}$ Entrevista realizada en Calama en junio de 2017.

${ }^{8}$ Nacida en septiembre de 1947 en San Pedro Estación. Hija de Natalio Ramos Cayo y Delfina Mendoza Cruz. Su mamá, doña Delfina, era hija de Casimiro Mendoza y Teresa Cruz. Los padres de la señora Teresa eran sus abuelitos Lucas Cruz Vilca y Feliciana Esquivel Puca. La señora Elizabeth recuerda que su tío José le contó que la señora Feliciana Esquivel Puca era originaria de Quetena.

${ }^{9}$ Entrevista realizada en San Pedro Estación en junio de 2016. ${ }^{10}$ Es la actual fabriquera de la iglesia grande. Es Prima de Miguelina Ramos. Su padre era Edmundo Alberto Cruz Huaca, casado con la señora Francisca Martínez. Su papá era hijo de don Tomás Cruz que se casó con doña Julia Huaca, originaria de Toconce. Don Tomás Cruz era hijo de Lucas Cruz Vilca y Feliciana Esquivel Puca.

${ }^{11}$ Edmundo Cruz Huaca nacido en 1949, en Choque et al. 2008:133.
${ }^{12}$ Ella se refiere a sus bisabuelos como sus abuelos. Entrevista realizada en Calama en junio de 2016. Es muy interesante su referencia a que los santitos no solo venían envueltos, sino que también se manejaban envueltos. Al respecto Walter Sánchez (comunicación personal, 2018) piensa que sería posible hacer una relación entre las cajas de madera que contienen santitos y las voces quechuas " $q$ 'epe. s. Carga o bulto para cargar a la espalda" y "q'epichiy. v. Hacer cargar; poner los bultos para que cargue una persona" y " $q$ 'epichay. v. Enfardelar, atar un bulto, preparar bultos de carga" (Diccionario Quechua-Español-Quechua 2005:500). Esta asociación surge dado que en su trabajo de campo en comunidades rurales de todo el valle alto de Cochabamba se ha encontrado con este vocablo para referirse a los cajones de santos (Sánchez 2015).

${ }^{13}$ La señora Venancia Cruz nació en 1933. Entrevista realizada en Calama en junio de 2017.

${ }^{14}$ La señora Ana Lobera Ramos vivió en la estancia de Agua Larga, también situada en la Cuenca del Río San Pedro, y cercana a Ojos de San Pedro. Entrevista realizada en Calama en junio de 2017.

${ }^{15}$ La señora Venancia Cruz es quien relata este conocimiento. La entrevista fue realizada en Calama en junio del año 2017.

${ }^{16}$ Es don Humberto Urdangarin Beltrán, hijo de Miguel Urdangarin y Ernestina Beltrán, quien relata este conocimiento. Entrevista realizada en Calama en junio de 2017.

${ }^{17} \mathrm{La}$ señora Venancia Cruz es quien relata este conocimiento. La entrevista fue realizada en Calama en junio de 2017.

${ }^{18}$ Es don Humberto Urdangarin Beltrán quien relata este conocimiento. Entrevista realizada en Calama en junio de 2017. 